\title{
Gross Capital Flows: Dynamics and Crises
}

\author{
Fernando Broner $^{\mathrm{a}} \quad$ Tatiana Didier $^{\mathrm{b}} \quad$ Aitor Erce $^{\mathrm{c}} \quad$ Sergio L. Schmukler ${ }^{\mathrm{b}, *}$
}

December 14, 2012

\begin{abstract}
This paper analyzes the behavior of international capital flows by foreign and domestic agents, dubbed gross capital flows, over the business cycle and during financial crises. We show that gross capital flows are very large and volatile, especially relative to net capital flows. When foreigners invest in a country, domestic agents invest abroad, and vice versa. Gross capital flows are also pro-cyclical. During expansions, foreigners invest more domestically and domestic agents invest more abroad. During crises, total gross flows collapse and there is a retrenchment in both inflows by foreigners and outflows by domestic agents. These patterns hold for different types of capital flows and crises. This evidence sheds light on the sources of fluctuations driving capital flows and helps discriminate among existing theories. Our findings seem consistent with crises affecting domestic and foreign agents asymmetrically, as would be the case under the presence of sovereign risk or asymmetric information.
\end{abstract}

Keywords: gross capital flows, net capital flows, domestic investors, foreign investors, crises

JEL Classification: F21, F30, F32, G01

${ }^{\mathrm{a}}$ CREI, Universitat Pompeu Fabra, and Barcelona GSE, ${ }^{\mathrm{b}}$ World Bank, ${ }^{\mathrm{c}}$ Bank of Spain

* E-mail addresses: fbroner@crei.cat, tdidier@worldbank.org, aerce@bde.es, sschmukler@worldbank.org 


\section{Introduction}

International capital flows have played an increasingly important role in the business cycles of high-income and middle-income countries, especially since the 1970s and during episodes of financial crises. As a consequence, a large literature has grown, analyzing the cyclical behavior of capital flows, mostly in emerging economies. This literature has concentrated on studying net capital flows, defined as the difference in gross capital flows, that is, the net purchases of domestic assets by foreign agents minus the net purchases of foreign assets by domestic agents. ${ }^{1}$ The literature shows that net capital flows are volatile and pro-cyclical and decline during crisis times. These patterns are more extreme in upper-middle-income countries and have even motivated the use of the term "sudden stops" to refer to the large collapses in net capital inflows that often accompany crises. ${ }^{2}$

While net capital flows have attracted significant attention, much less is known about the behavior of gross capital flows. Yet, understanding the behavior of gross capital flows seems crucial, especially given that capital flows by foreign and domestic agents have become very important and are likely driven by different factors. For example, agents might invest directly in a firm located in a foreign country if they have access to a technology that is superior to that of domestic agents, a foreign asset might be more attractive to some agents if it provides a better hedge to their non-pledgeable labor income, or sovereign risk might make the return of an asset depend on the residency of the agent who holds it. As a result, it seems reasonable to expect that gross capital flows by foreign and domestic agents behave differently both over the cycle and during crises, as we in fact find in this paper.

Several papers analyze long-run trends in gross capital flows showing that the large flows

\footnotetext{
${ }^{1}$ See, for example, Dornbusch, Goldfajn, and Valdés (1995), Kaminsky, Lizondo, and Reinhart (1998), Broner and Rigobon (2006), Levchenko and Mauro (2007), and Mendoza (2010).

${ }^{2}$ See, for example, Calvo (1998), Calvo, Izquierdo, and Mejía (2008), and Cavallo and Frankel (2008).
} 
have resulted in large gross international investment positions (Lane and Milesi-Ferretti, 2001 and 2007, Kraay et al., 2005, Devereux, 2007, Gourinchas and Rey, 2007a and 2007b, and Obstfeld, 2012). But there are few studies on the cyclical behavior of gross capital flows. The literature has so far mostly focused on characterizing episodes of abrupt reversals in capital inflows into those driven by foreign agents, or true sudden stops, and those driven by domestic agents, or episodes of capital flight (Powell, Ratha, and Mohapatra, 2002, Faucette, Rothenberg, and Warnock, 2005, Cowan et al., 2008, Janus and Riera-Crichton, 2009, Calvo, 2011, Rothenberg and Warnock, 2011, Calderon and Kubota, forthcoming, and Forbes and Warnock, forthcoming). Other studies examine the behavior of particular types of gross capital flows during specific events (Frankel and Schmukler, 1996, Kim and Wei, 2002, Choe, Kho, and Stulz, 2005, Albuquerque, Bauer, and Schneider, 2007, and Milesi-Ferretti and Tille, 2010). Evidence for the U.S. suggests that there is a positive correlation between domestic purchases of foreign equity and foreign purchases of domestic equity (Dvorak, 2003, Hnatkovska, 2010, and Tille and van Wincoop, 2010).

Because of the limited research on gross capital flows, many important questions remain unanswered. For example, are periods in which foreign agents purchase domestic assets also periods in which domestic agents sell foreign assets? Is there a positive or negative correlation between capital flows by foreign and domestic agents? What is the behavior of gross capital flows over the business cycle and during financial crises? We know that crises are associated with reductions in net capital inflows. But are these reductions on average due to sales of domestic assets by foreign agents, purchases of foreign assets by domestic agents, or both? How large and how volatile are gross capital flows relative to net capital flows? Do all types of gross capital flows behave similarly or are aggregate flows driven by particular flow types? 
In this paper, we document a number of stylized facts about the dynamics of gross capital flows, which provide answers to the questions mentioned above. More specifically, we study the cyclical behavior of capital inflows by foreign agents $(C I F)$ and capital outflows by domestic agents (COD), our two measures of gross capital flows. ${ }^{3}$ Positive $C I F$ and $C O D$ are both associated with increases in gross international investment positions. To construct $C I F$ and $C O D$, we use balance of payments data from the International Financial Statistics of the International Monetary Fund from 1970 to 2009 for 103 countries. CIF is equal to the net purchases of domestic assets by non-residents; namely, it is the sum of all liability inflows. $C O D$ is equal to the net purchases of foreign assets by domestic agents; in other words, it is the negative of the sum of all asset inflows including international reserves. Net capital flows are equal to the difference $C I F-C O D$ and total gross flows are equal to the sum $C I F+C O D$.

Our main findings are the following. (i) The magnitude and the volatility of gross capital flows ( $C I F$ and $C O D)$ are large both in absolute terms and relative to the size and the volatility of net capital flows. They have also increased over the four decades encompassing the 1970s to the 2000s, while the size and the volatility of net capital flows have remained stable. This reflects an increasingly positive correlation between $C I F$ and $C O D$. (ii) Gross capital flows are pro-cyclical. In other words, during expansions foreign agents increase their purchases of domestic assets and domestic agents increase their purchases of foreign assets. During contractions, the opposite occurs. Moreover, during crises, total gross capital flows collapse or retrench. (iii) Crises that occur during periods of global financial turbulence are associated with particularly large retrenchments. Moreover, retrenchments take place during banking, currency, and debt crises. (iv) These patterns reflect reductions in every type of gross capital flows during crises, including

\footnotetext{
${ }^{3} C I F$ and $C O D$ should not be confused with gross purchases of domestic assets by foreigners and gross purchases of foreign assets by domestic residents. Information on such gross asset trades is not consistently available from the balance of payments statistics for a large sample of countries.
} 
direct investments, other investments, portfolio debt, and portfolio equity. The behavior of reserves differs across income groups, playing an important role in the contraction of capital flows in middle-income countries and none in high-income ones.

These results have important implications for the theories of capital flows. Different classes of models make different predictions regarding the behavior of gross capital flows. Therefore, the evidence we provide in this paper helps discriminate among several of these existing theories. As we explain below, our findings seem consistent with crises affecting domestic and foreign agents asymmetrically, as would be the case under the presence of sovereign risk or asymmetric information.

The rest of the paper is organized as follows. Section 2 describes the data. Section 3 characterizes the comovement of capital flows by foreign and domestic agents. Section 4 analyzes the behavior of gross capital flows over the business cycle and during crises. Sections 5 and 6 show results for countries of different income groups and for different types of crises, respectively. Section 7 discusses some theoretical implications. Section 8 concludes.

\section{Data}

To document worldwide patterns of capital flows by domestic and foreign agents, we assemble a comprehensive data set on gross capital flows, including not only aggregate capital inflows and outflows, but also their components, reflecting the different flow types. The data come from the analytic presentation of the IMF's Balance of Payments Statistics Yearbooks (BOP). ${ }^{4}$ The IMF's BOP data set provides country-level data, on an annual basis since 1970, on different types of

\footnotetext{
${ }^{4}$ Debt refinancing and rescheduling entries, which involve changes in existing debt contracts or replacement by new ones generally with extended debt service payments, are excluded from our data set. In the analytic presentation of the IMF's BOP, the credit and debt entries derived from the new contracts are computed within a country's financial account as exceptional financing items. Therefore, our analysis excludes these credits and debits as they generally do not involve new capital inflows to the reporting country.
} 
capital flows measured in U.S. dollars. Fundamental to our goal, this data set allows us to disentangle, respectively, capital outflows by domestic agents (COD) and capital inflows by foreigners $(C I F)$, which are measured as flows related to the reporting country's assets and liabilities vis-à-vis non-residents. In other words, $C I F$ is recorded as capital inflows to the reporting economy by foreign agents, indicating an increase in foreigners' holdings of domestic assets. Analogously, $C O D$ stands for flows from the reporting economy, where positive values correspond to an increase in the holdings of foreign assets by domestic agents. ${ }^{5}$ Hence a positive $C O D$ should be interpreted as capital outflows by domestic agents, whereas a negative $C O D$ means capital repatriation.

Our data set also allows us to analyze the behavior of the different types of capital flows. These flows are classified as: direct investments (often called foreign direct investment or FDI), portfolio flows, other investments (including bank flows, other public and private loans, and trade credit), and international reserves. ${ }^{6}$ Portfolio flows are further divided into equity and debt flows. The data capture both private and public flows. Therefore, $C I F$ (the measure of aggregate capital inflows by foreigners) is equivalent to the sum of the following inflows: direct investments in the reporting economy, portfolio investment liabilities, and other investment liabilities. Similarly, $C O D$ is the aggregation of outflows of direct investments abroad, portfolio investment assets, other investment assets, and international reserve assets. As our aim is to shed light on both how large and how volatile capital flows are, we scale $C I F$ and $C O D$ and their components by trend GDP throughout the paper. ${ }^{7}$

\footnotetext{
${ }^{5}$ These measures however do not capture increases in foreigners' (domestic agents') holdings of domestic (foreign) assets that are due to valuation effects.

${ }^{6}$ Because of their relatively small size and scarcity of data, we exclude flows in financial derivatives from our analysis.

${ }^{7}$ Trend GDP is calculated by applying the Hodrick-Prescott filter, using a parameter of 100, to the series of nominal GDP in U.S. dollars. Nominal GDP is obtained from the World Bank's World Development Indicators and is complemented with data from the IMF's World Economic Outlook if the data from the original source are missing.
} 
The database we compile covers 103 countries over the 1970-2009 sample period. Our sample of countries is based mostly on data availability. We concentrate on high-income and middle-income countries, following the World Bank classification as of July 2008. In particular, we classify our sample of 103 countries into groups according to their income levels as measured by their GNI per capita in 2005. Lower-middle-income countries are those with GNI per capita below 7,500 U.S. dollars (36 percent of the sample). Upper-middle-income countries are those with GNI per capita between 7,500 and 15,000 U.S. dollars (26 percent of the sample). Highincome countries are those with GNI per capita above 15,000 U.S. dollars (38 percent of the sample). In many instances throughout the paper, we use the more general term middle-income countries to refer to these two groups of lower-middle-income and upper-middle-income countries.

Our database excludes countries that are either very small or very poor, that is, those that fall in the low-income group. Small countries are a concern because they might display an artificially high volume of financial transactions due to their role as offshore financial centers or tax havens. A country is considered small if its gross national income (GNI) in 2005 is less than four billion U.S. dollars, PPP adjusted. We exclude 30 countries from the analysis for this reason, among them Belize, Guyana, and Maldives. Poor or low-income countries typically depend heavily on official aid flows that might behave very differently from private capital flows, which represent the bulk of the flows in other countries, and are thus beyond the scope of our analysis. We exclude 35 countries with GNI per capita smaller than 2,000 U.S. dollars (PPP adjusted) in 2005, among them Bangladesh, Cameroon, Ethiopia, Niger, Sudan, and Yemen. We include India, Vietnam, and Pakistan, with a GNI per capita slightly above 2,000 U.S. dollars in 
In order to analyze capital flows around crises, we use several indicators available in the literature that capture the beginning of crises on an annual basis. All indicators are updated until 2009. Banking and currency crises come from the dating of crises available in Laeven and Valencia (2008 and the website update). A country has a banking crisis when its financial sector experiences a large number of defaults and financial institutions and corporations face great difficulties repaying contracts, thus non-performing loans increase sharply and most of the aggregate banking system capital is exhausted. Following the methodology in Frankel and Rose (1996), a country experiences a currency crisis if there is a nominal depreciation of the exchange rate of at least 30 percent, which also represents at least a 10 percent increase in the rate of depreciation over the previous year. ${ }^{9}$ Debt crises, comprising both domestic and external debt crises, are those identified in Reinhart and Rogoff (2009). To complete the data set for the countries in our sample, we complement the Reinhart and Rogoff (2009) dating of debt crises with data from Standard \& Poor's. In particular, a country has debt crises in the years in which downgrades to default levels occur for the sovereign local currency debt (domestic debt crises) or for the sovereign foreign currency debt or the sovereign foreign currency bank loans (external debt crises).

We create a composite crisis indicator that takes into account all of these measures of banking, currency, and debt crises. A year for a given country is a crisis year if any of these indicators signals a crisis for that country in that year. Out of the 39 countries classified as highincome, 27 have a crisis during our sample period, and of the total 1,300 country-year

\footnotetext{
${ }^{8}$ We use 2005 data on both GNI and GNI per capita because employing more updated data would have significantly reduced our sample coverage. Moreover, the ranking of countries relative to the thresholds used in this paper does not change considerably over time.

${ }^{9}$ We use this indicator of currency crises because most indicators described in the literature are constructed using data on reserves, one of our variables of interest, hence making them less appropriate for our analysis of capital flows.
} 
observations 45 are crisis years. As expected, a substantially higher fraction of the upper-middleincome countries ( 25 out of 26 countries) have at least one crisis during our sample period, when compared to the high-income countries. Moreover, upper-middle-income countries typically have more than one crisis. A total of 88 (out of 702) country-year observations are crisis years. Furthermore, all of the 38 lower-middle-income countries have a crisis during our sample period and 105 (out of 1,050) country-year observations are crisis observations. Appendix Table 1 lists all the crisis years per country that appear in our sample.

\section{Behavior of Capital Flows by Foreign and Domestic Agents}

As a first step to studying the behavior of gross capital flows over the past decades, Figure 1 shows the evolution of $C I F$ and $C O D$ (normalized by trend GDP) for a sample of nine countries. The figure shows a strong positive comovement between $C I F$ and $C O D$, which indicates that capital inflows by foreigners and outflows by domestic agents move in tandem. Namely, when foreign investors pour capital into domestic markets, domestic agents increase their investments abroad. Moreover, this correlation seems to hold not only during non-crisis years, but also during crisis years, when a retrenchment in flows is observed. The figure also suggests that gross capital flows behave very differently from net capital flows. For example, during the 2008 global financial crisis gross capital flows experienced a sharp drop around the world, even though net flows remained relatively stable. This behavior suggests that gross capital flows are more volatile than net capital flows. In the rest of this section, we document more formally the joint behavior of $C I F$ and $C O D$.

Table 1 presents summary statistics of total gross capital flows $(C I F+C O D)$, gross capital flows $(C I F$ and $C O D)$, and net capital flows $(C I F-C O D)$. It shows that gross capital flows, 
measured as a percentage of trend GDP, have increased over time around the world. Table 1 reaffirms the trends in Figure 1 and suggests the presence of a broad process of financial globalization, where capital flows by both domestic and foreign agents have increased, especially in high-income and upper-middle-income countries. For example, $C I F$ increases from about 4.8 percent ( 0.8 percent) of trend GDP for the median high-income (upper-middle-income) country in the 1980 s to more than 15 percent (5 percent) of trend GDP in high-income (upper-middleincome) economies in the 2000s. We observe similar patterns for COD. Despite the significant attention in the literature, there is no clear evidence of such a positive trend in net capital flows. If anything, net capital flows have decreased over time for both high-income and lower-middleincome countries. Therefore, to gauge the extent of globalization it seems important to focus on gross capital flows as opposed to net capital flows.

In addition to size, Table 1 also shows that the volatility (understood as the standard deviation) of gross capital inflows has increased significantly over the years, more than that of net capital flows. For high-income countries, the median standard deviation of $C I F(C O D)$ is 9.2 (8.1) percent of trend GDP during the 2000s, compared to 2.7 (2.3) during the 1970s. In uppermiddle-income and lower-middle-income countries, the volatility of gross flows has also increased, but in a less pronounced way. For example, the median standard deviation of $C I F$ $(C O D)$ is 5 (4.9) percent of trend GDP for upper-middle-income countries in the 2000s, compared to 3.1 (3) during the 1970s. In lower-middle-income countries, we observe an even less pronounced increase. The standard deviation of $C I F(C O D)$ goes from 2.3 (1.8) in the 1970s to 3.9 (3.4) in the $2000 \mathrm{~s}^{10}$

\footnotetext{
${ }^{10}$ These increases do not take place if one analyzes the coefficient of variation, i.e. the standard deviation divided by the mean. However, the coefficient of variation does not seem to be the more relevant statistic for measuring the volatility of capital flows. For example, the coefficient of variation is large for net flows because average net flows are close to zero for many countries in the sample.
} 
The statistics in Table 1 indicate that the volatility of gross capital flows is larger for high-income countries than for middle-income countries, especially during the 2000s. These patterns stand in contrast with the well-known fact that net capital flows are more volatile in middle-income countries. Indeed, over our entire sample period, the median standard deviation of net capital flows is 3.9 and 5.6 for high-income and upper-middle-income countries, respectively. In contrast to the observed patterns in gross capital flows, the volatility of net capital flows has remained relatively stable over the past three decades for countries across all income levels. The standard deviation of net capital inflows in upper-middle-income countries stands at 3.9 during the 1970 s, increases to 4.2 during the 1990 s, and declines back to 3.9 during the 2000s. In high-income and lower-middle-income countries, the volatility of net capital flows increases slightly over time. In lower-middle-income countries, the standard deviation of net flows is 4.1 percent of trend GDP in the 1980s and reaches 4.4 during the $2000 \mathrm{~s}$.

The patterns documented thus far suggest an increasing importance of gross capital flows, particularly starting in the 2000s. Figure 2 further illustrates how gross flows have increased over time, while net capital flows have remained relatively stable. The figure shows ellipses corresponding to the bivariate Gaussian distribution of $C I F$ and $C O D$. Each ellipsis summarizes the distribution of the $C I F$ and $C O D$ observations (one pair per country-decade) separately for the 1980s, 1990s, and 2000s. The ellipses are centered at the mean of these variables and their shape is determined by their covariance matrix. The main axes that give direction to the ellipses are determined by the first and second principal components of the covariance matrix, while the boundaries of the ellipses capture two standard deviations along the two principal components, hence encompassing 86 percent of the total probability mass. The 45degree line in Figure 2 captures country-decade observations for which net capital flows are zero 
(i.e., $C O D$ is on average equal to $C I F$ over the decade). Hence, a move along the 45 -degree line denotes an expansion in gross capital flows, whereas an increase in the distance between the boundaries of an ellipsis and the 45-degree line indicates larger net capital flows. Overall, the ellipses in Figure 2 show that capital flows by both foreign and domestic agents have increased steadily over time, and especially so in the 2000s, while net flows have not changed considerably over the decades.

In the working paper version of this paper, Broner et al. (2010), we also analyze the volatility of the different types of capital flows across income groups. Among inflows by foreigners, other investments are the most volatile flow type for all income levels. This stands in contrast to existing perceptions that portfolio flows are the most volatile type of flow. In fact, for upper-middle-income and lower-middle-income countries direct investments are also more volatile than portfolio flows. Among outflows by domestic residents, other investments are again more volatile than both portfolio flows and direct investments for all income groups. International reserves, however, are the most volatile flow type by domestic residents for uppermiddle-income and lower-income countries.

Our results give support to a generalized process of financial globalization with capital flows by both foreign and domestic agents increasing significantly. We next assess whether this suggested positive correlation between $C I F$ and $C O D$ indeed holds when performing a crosscountry and time-series comparison over the four decades under study. More formally, we estimate the following regressions:

$$
\begin{aligned}
& C I F_{c, t}=\alpha_{c}+\gamma_{c} \cdot t+\beta \cdot C O D_{c, t}+\varepsilon_{c, t}, \\
& C O D_{c, t}=\alpha_{c}+\gamma_{c} \cdot t+\beta \cdot C I F_{c, t}+\varepsilon_{c, t},
\end{aligned}
$$

where we allow for different intercepts (country dummies) and different trends (country-trend 
dummies) across countries. To prevent individual countries from driving the results, we scale $C I F$ and $C O D$ by trend GDP and also standardize these variables by de-meaning and scaling them by their corresponding standard deviations on a country-by-country basis. The results are reported in Table 2, where countries are split into our three income groups. We present estimations for the whole sample as well as separately for each of the decades under analysis.

The estimations provide robust evidence that $C I F$ is positively correlated with $C O D$. In other words, when foreigners invest in a country, its domestic agents invest abroad. Such a positive correlation generates an expansion in financial globalization, in which a country's international assets and liabilities grow. Conversely, when foreign capital leaves, domestic residents repatriate the capital they placed abroad, which generates a retrenchment in gross capital flows. In line with the graphical evidence, the positive comovement between gross capital flows has risen over time as the increase in the magnitude of the coefficients indicates. Moreover, the estimated coefficient increases with countries' income level. The estimated coefficient for lower-middle-income countries is 0.27 , while the same estimated parameter is 0.44 for upper-middle-income countries and 0.78 for high-income countries. ${ }^{11}$

In sum, the evidence in this section suggests that capital flows by domestic and foreign agents are large and volatile, and increasingly so since the 1970s, surpassing the size and, in most cases, the volatility of net capital flows. Furthermore, $C I F$ and $C O D$ are positively correlated. In other words, there are periods of financial globalization and periods of retrenchment. Next, we investigate the cyclical properties of gross capital flows and their behavior around financial crises.

\footnotetext{
${ }^{11}$ We have also estimated other regressions that control for global factors, in particular World GDP growth, U.S. GDP growth, and the VIX market volatility index. We do not report these regressions here, but the results are qualitatively and quantitatively similar to those in the paper.
} 


\section{Cyclical Behavior of Gross Capital Flows}

To explore the cyclical properties of gross capital flows, we analyze the behavior of $C I F$ and $C O D$ over the business cycle and around crises. We provide empirical evidence that financial globalization tends to occur during periods of economic expansions and retrenchments tend to occur during periods of economic contractions or crises.

\subsection{Gross Capital Flows over the Business Cycle}

To analyze the cyclical properties of gross capital flows, we estimate the following equation:

$$
Y_{c, t}=\alpha_{c}+\gamma_{c} \cdot t+\beta \cdot X_{c, t}+\varepsilon_{c, t},
$$

where $Y_{c, t}$ stands for $C I F, C O D$, or total gross flows $(C I F+C O D)$ and $X_{c, t}$ represents either the trade balance in goods and services or a measure of GDP fluctuations. The trade balance in goods and services is scaled by trend GDP, demeaned and standardized by its standard deviations at the country level. ${ }^{12}$ Our measure of business cycles is based on the growth rates of real GDP, measured in constant units of the local currency. ${ }^{13,14}$

The results are reported in Table 3. They show that the trade balance in goods and services is strongly associated with capital inflows by foreigners for all income groups. For highincome countries, the trade balance is also strongly correlated with capital outflows by domestic agents. In fact, the estimated coefficients on $C I F$ and $C O D$ are very similar. However, in uppermiddle-income and lower-middle-income countries, the estimated coefficients of the trade balance on $C I F$ are significantly larger than those on $C O D$, suggesting a stronger association between the trade balance and the behavior of foreign investors.

\footnotetext{
12 The data on the trade balance come from the IMF's Balance of Payment Statistics Yearbooks.

${ }^{13}$ The GDP series come from the World Bank's World Development Indicators and are complemented with data from the IMF's World Economic Outlook if the data from the original source are missing.

${ }^{14}$ As an alternative measure of business cycles, we also used a measure of the output gap based on the HodrickPrescott filter. The results obtained were qualitatively similar to the ones reported here.
} 
Regarding the dynamics of gross capital flows over the business cycle, we find that gross capital flows expand during good times, while they decline during bad times. In other words, we find that not only capital flows by foreigners are pro-cyclical, but capital outflows by domestic agents are pro-cyclical as well. Namely, domestic agents invest more abroad during good times, when the domestic economy is growing in real terms. Therefore, as shown by the estimated coefficients on $C I F+C O D$, we observe expansions in financial globalization (when a country's international assets and liabilities expand) during good times. Analogously, during the contractionary phase of the business cycle, there is a retrenchment in gross capital flows.

The results in Table 3 complement the widely documented evidence on the procyclicality of net capital inflows. The results here show that during booms foreigners increase their purchases of domestic assets and domestic agents augment their investments abroad. The patterns for middle-income economies suggest that foreigners drive to a large extent the changes in net capital inflows. In contrast, in high-income countries, domestic agents play a much more important role in explaining the behavior of net flows.

\subsection{Gross Capital Flows during Crises}

To analyze how gross capital flows behave during crises, we start by providing some descriptive statistics comparing the behavior of $C I F$ and $C O D$ during crisis and non-crisis years. Table 4 shows that both capital inflows by foreigners and capital outflows by domestic agents decline during crisis years for countries from all income groups. For example, $C I F$ falls by more than 40 percent for lower-middle-income countries, while $C O D$ decreases by almost 60 percent. Similarly, we observe declines of between 14 and 40 percent in gross capital flows in highincome countries. In upper-middle-income countries, the retrenchment in gross capital flows is 
even stronger. CIF declines from inflows of 6.5 percent of trend GDP to actual outflows of 2.9 percent of trend GDP and COD goes from outflows of 5.8 percent of trend GDP to inflows of 2.5 percent of trend GDP. ${ }^{15}$

Despite the similarities in the dynamics of gross capital flows among countries from all income levels, the behavior of net capital flows is rather contrasting. While in high-income countries net capital inflows increase during crises, in middle-income countries, especially in upper-middle-income ones, net capital inflows decline. This evidence is consistent with the retrenchment by domestic agents being stronger than the retrenchment by foreigners in highincome countries, but weaker in middle-income economies.

An event study analysis of gross capital flows around crises reinforces the evidence above. For this exercise, we focus on the dynamics of $C I F$ and $C O D$ not only during crisis years, but also in the run-up to crises and the immediate aftermath by analyzing the two years preceding and following crises. We estimate the following equation:

$$
Y_{c, t}=\alpha_{c}+\gamma_{c} \cdot t+\sum_{i=-2}^{i=2} \beta_{i} \cdot \text { Crisis }_{c, t+i}+\varepsilon_{c, t},
$$

where $Y_{c, t}$ stands for our standardized measures of $C I F$ or COD and Crisis is the composite crisis indicator. ${ }^{16}$ Once more, we perform the analysis by pooling countries in different ways.

Table 5 shows the dynamics of gross capital flows during crises, pooling all countries together. The table shows the behavior of $C I F$ and $C O D$ and also the behavior of their respective components. The results in Table 5 provide robust evidence of retrenchment. That is, capital flows by both foreign and domestic agents decline during crisis years. In particular, the first

\footnotetext{
${ }^{15}$ To the extent that official flows are unlikely to decline during crises, the milder reaction of capital flows in lowermiddle-income countries when compared to upper-middle-income ones might be explained by the relative size of these official flows.

${ }^{16}$ The results are qualitatively similar if we add year dummies as controls.
} 
column of Table 5 shows that both $C I F$ and $C O D$ are negative and statistically different from zero during the crisis years. Table 5 also presents Wald statistics that test if the level of flows during the crisis years is significantly smaller than the one observed in the run-up to crises. Because it is sometimes difficult to exactly pinpoint the year of a crisis and because crises are sometimes anticipated and other times provoke delayed reactions, we also report Wald statistics that include alternatively the year before and the year after crises, vis-à-vis previous years. The Wald tests show that the decline in capital inflows by foreigners and capital outflows by domestic agents during the crisis years (in comparison to the average flow in the previous two years) is statistically significant. Furthermore, the results show that gross capital flows remain at depressed levels, or decline even further, during the two-year period after the onset of the crises.

The decline in $C I F$ and $C O D$ during crises is not only statistically significant, but also economically large. The top-left panel of Figure 3 shows the average behavior of capital flows around crises. In particular, capital inflows by foreigners decline from 1.6 percent of trend GDP two years before the crises to -2.3 percent of trend GDP the year of the crises, and they fall further to -3 percent of trend GDP the year after the crises. The figure shows a similar pattern for the capital outflows by domestic agents. They collapse from 0.3 percent of trend GDP two years before the crises to -1.8 percent of trend GDP the year of the crises and -0.5 percent of trend GDP the year after the crises.

Are these patterns of gross capital flows widespread across flow types? This is important because, while the first column of Table 5 shows the results for $C I F$ and $C O D$, some types of flows might behave in different ways and particular types of flows might be driving the overall results. However, Table 5 shows that the results using aggregate gross flows are similar to those decomposing capital inflows and outflows into their components. In particular, among CIF, 
direct investments, other investments, and portfolio debt and equity flows collapse during crises. Among $C O D$, the same components and reserves fall around crisis times. The results also show that there are differences in the timing of the collapse for the different types of flows. Most notably, reserves start declining the year before the crises erupt and direct investments fall more in the subsequent two years. We discuss in more detail the behavior of the different types of flows next, where we analyze the evidence for different income groups.

\section{Dynamics of Gross Capital Flows across Income Levels}

The event studies reported in the previous section might hide important differences across different types of countries. In particular, the literature has emphasized that net capital flows are pro-cyclical in emerging economies (typically the upper-middle-income countries), but much less is known about the behavior of gross capital flows across the different income groups. This is what we study in this section, which also tests the robustness of the results reported earlier.

When analyzing gross capital flows for different income groups, it seems important to decompose them by flow type (direct investments, other investments, portfolio investments, and reserves) because their relative size varies significantly across these income groups, as reported in the working paper version of this paper, Broner et al. (2010). For example, in high-income countries, other investment flows (which capture bank flows among others) are the largest component of both $C I F$ and $C O D$, and represent around 50 percent of these flows. In middleincome countries, around half of $C I F$ takes the form of direct investments. For the median uppermiddle-income (lower-middle-income) country, direct investments stand at 2.2 (2.5) percent of trend GDP in comparison to portfolio investments of $0.6(0.1)$ percent and other investments of 1.6 (1.9) percent over our sample period. On the other hand, international reserves represent 46 
(58) percent of $C O D$ in upper-middle-income (lower-middle-income) countries.

Not all types of flows across countries have accompanied the striking increase in gross capital flows over time. While direct investments have captured the bulk of the increase in $C I F$ in middle-income countries since the 1990s, other investment flows have increased significantly in high-income countries. In lower-middle-income countries, other investment flows by foreign agents have actually declined since the 1980s. While other investment outflows by domestic agents have increased considerably during the 2000s for all income groups, for middle-income countries the expansion of international reserves also explains a large part of the increase in COD.

Table 6 shows the results of estimating Equation (4) separately for the different income groups. The results for aggregate inflows and outflows provide robust evidence of retrenchment, that is, both $C I F$ and $C O D$ decline for countries from all income groups during crisis years. Moreover, as shown in Figure 3, the median decline in $C I F$ and $C O D$ during crises is rather large. For instance, $C I F$ in the median high-income country declines from inflows of 7.5 percent of trend GDP during the pre-crisis year to outflows of 5.9 percent during the first post-crisis year. For the median upper-middle-income country, these flows reverse from 0.3 to -2.7 percent of trend GDP over the same period. In lower-middle-income countries, CIF declines from around 0.2 percent of trend GDP in the year preceding the turmoil period to around -2.2 percent of trend GDP during the year following the onset of the crises. Similar numbers are estimated for $C O D$ in high-income countries. For middle-income countries, although the decline in $C O D$ during the crisis year is of similar magnitude to that of $C I F$, it recovers to pre-crisis levels faster as shown in the bottom panels of Figure 3. For all income groups, the decline in $C I F$ is larger than in $C O D$, implying a decline in net capital inflows during crisis and post-crisis years relative to pre-crisis 
years.

Table 6 also shows that the observed patterns of $C I F$ and $C O D$ are present in the different components of gross capital flows. Namely, no single component of $C I F$ and $C O D$ across countries with different income levels is responsible for the overall dynamics of gross capital flows. There is, however, heterogeneity in the behavior of the different components, which partly reflects the relative size of the different flows in each income group.

Among high-income countries, all of the components of CIF (direct investments, portfolio debt and portfolio equity flows, and other investments) fall during crises. Other investments are the flows that experience the sharpest drops. These same components of $C O D$ decline and the contractions are more similar across types of flows. Reserves, on the other hand, do not decrease during crises and they actually increase the year after the crises. Among uppermiddle-income countries, the decline in gross capital inflows occurs in direct investments, other investments, and marginally in portfolio debt flows. Among the components of gross capital outflows, there is a decline in direct investments and portfolio equity flows. In contrast to highincome countries, reserves also contract. In fact, the decline in reserves starts the year before the crises. In lower-middle-income countries, the pattern is broadly similar to the one in uppermiddle-income countries. Among gross capital inflows, there is a large decline in other investments, smaller declines in portfolio debt flows and direct investments, and a marginal decline in portfolio equity flows. Among gross capital outflows, there is a large decline in reserves starting the year before the crises, and marginal declines in direct investments and other investments.

In sum, other investments seem relevant for the behavior of gross capital inflows in all income groups. Portfolio flows in general and outward direct investments are more important in 
high-income countries. Inward direct investments fall more in statistical terms in upper-middleincome countries. Moreover, while international reserves are not affected by crises in highincome countries, upper-middle-income countries and to some extent also lower-middle-income ones do reduce substantially their reserves during crises. ${ }^{17}$

\section{Dynamics of Gross Capital Flows across Crisis Types}

The analysis so far includes all kinds of crises by using a single composite crisis indicator that pools together several types of financial crises for a particular country in a given year. But it is possible that capital flows respond differently to crises of different types. For example, MilesiFerretti and Tille (2010) argue that during the 2008 global financial crisis capital flows around the world declined significantly. This pattern also shows up in our data and we observe significant retrenchments in gross capital flows in all income groups during 2008 and 2009 in comparison to the pre-crisis period (see the working paper version of this paper, Broner et al., 2010). However, is this a general feature of global crises? And are global crises driving our results on retrenchment? In addition, our sample encompasses crises related to the banking system, the currency, and the domestic and external debt. The different components of capital flows might react differently to these types of crises.

To test the effects of different crises, we perform two separate types of exercises, each reestimating Equation (4). The first one splits the crises we used earlier into domestic and global episodes. We define global crises as those crises that happen in the following years: 1980 to 1984 (the Latin American debt crisis), 1998 to 1999 (the Asian and Russian crises), and 2008 to 2009 (the global financial crisis). We classify all the other crises as domestic crises. We estimate

\footnotetext{
${ }^{17}$ There is a growing literature on the management of international reserves. See, for example, Alfaro and Kanczuk (2009), Durdu, Mendoza, and Terrones (2009), Jeanne and Ranciere (2011), and Bianchi, Hatchondo, and Martinez (2012).
} 
the following equation:

$$
Y_{c, t}=\alpha_{c}+\gamma_{c} \cdot t+\sum_{i=-2}^{i=2} \beta_{i}^{d} \cdot \text { Domestic Crisis } s_{c, t+i}+\sum_{i=-2}^{i=2} \beta_{i}^{g} \cdot \text { Global Crisis }_{c, t+i}+\varepsilon_{c, t}
$$

where the only change relative to Equation (4) involves using Domestic Crisis and Global Crisis instead of Crisis to capture the different types of episodes. As alternative definitions of global crises, we also excluded the crises that fall in 1980 to 1984 and, in a different exercise, we only used the global financial crisis of 2008-2009. We obtained results similar to the ones reported here.

The estimates shown in Table 7 suggest that global crises are not the only drivers of our previous results. Both $C I F$ and $C O D$ decline significantly during domestic crisis years according to the Wald tests. While $C I F$ during the domestic crisis years is statistically smaller than its average during the preceding two years, there is some degree of anticipation in $C O D$, which starts falling before the crises begin.

The results in Table 7 also suggest that $C I F$ and $C O D$ decline more and more abruptly during years of global crises. Namely, as opposed to before domestic crises, CIF and COD are positive before global crises and the magnitude of the coefficients during and after global crises is larger. Moreover, the decline in $C I F$ and $C O D$ during global crises is in fact economically larger than during domestic crises. While $C I F$ falls by around 2 percentage points of trend GDP between the year before and the year of domestic crises (from -1.1 to - 3 percent of trend GDP), it declines 6.2 percentage points (from 4.8 to -1.4 percent of trend GDP) over the same window around global crises. Similarly, the decline in $C O D$ is also more accentuated during global crises (-2.8 percentage points of trend GDP) than during domestic crises $(-0.2$ percentage points of trend GDP). These patterns hold when analyzing the different components of $C I F$ and $C O D$.

In sum, the results in Table 7 show that the behavior of foreign and domestic agents 
during global crises is in line with their behavior during domestic crises; the estimates confirm a generalized retrenchment of gross capital flows around these events. But the estimates also show that capital flows react more strongly during years of global crises than during years of domestic crises.

The second exercise splits the crisis years in years of banking crises, currency crises, and debt crises. To do so, we use the variables described in Section 2, which are actually the input to assemble the composite crisis indicator. We estimate the equivalent of Equation (4) separately for each type of crisis.

Table 8 reports the results that show a significant retrenchment in both $C I F$ and $C O D$ around the three types of crises. Nonetheless, there is heterogeneity in the dynamics of the different components of gross capital flows around banking, currency, and debt crises. While there is some degree of retrenchment across all of the CIF components during banking and currency crises, portfolio equity flows do not decline during debt crises although the other components do. Among the $C O D$ components, only reserves and direct investments decline significantly around the three types of crises. During banking crises, we observe a widespread retrenchment across the different types of capital flows by domestic agents, when all of the flows fall significantly. Portfolio debt flows also decline during currency crises whereas other investments also fall during debt crises.

In the working paper version of this paper, Broner et al. (2010), we also report results in which we split crisis years into mild crisis years (when a country experiences one, and only one, type of crisis in a given year) and severe crisis years (when a country faces more than one type of crisis within a given year). The results suggest that the reaction of domestic and foreign agents is stronger during severe crisis episodes. The results also suggest that the fall in capital flows by 
domestic agents in the aftermath of severe crises is more short-lived and reverses during the subsequent two years.

\section{Theoretical Implications}

The findings in this paper have important implications for theories of international capital flows. There is a growing literature in international macro-finance that brings portfolio choice and asset pricing considerations into dynamic stochastic general equilibrium (DSGE) models of international macroeconomics. Many of these papers focus on the long-run composition of countries' portfolios. $^{18}$

Two recent contributions that emphasize the high-frequency behavior of gross capital flows are Hnatkovska (2010) and Tille and van Wincoop (2010). Both papers try to explain the positive correlation between domestic purchases of foreign equity and foreign purchases of domestic equity in the U.S. To account for this fact, they both provide DSGE models in which crises are the result of negative productivity shocks, in the absence of financial or other types of frictions. Hnatkovska (2010) shows that a preponderance of productivity shocks in the nontradable sector can lead to a positive correlation in gross equity flows. Tille and van Wincoop (2010) show that productivity shocks can account for the positive correlation of gross capital flows if they are associated with time variation in expected returns and risk. These models are successful at matching some features of the data, but not all. For instance, Tille and Van Wincoop (2010)'s model predicts that gross capital flows should be counter-cyclical, which is at odds with the evidence presented in this paper. While Hnatkovska (2010)'s model does predict that gross capital flows should be pro-cyclical, it also predicts a strong negative correlation

\footnotetext{
${ }^{18}$ See, for example, Kraay and Ventura (2000), Evans and Hnatkovska (2005), Coeurdacier, Kollmann, and Martin (2010), Devereux and Sutherland (2010 and 2011), and Pavlova and Rigobon (2010). Pavlova and Rigobon (forthcoming) provide a short survey of this literature.
} 
between portfolio equity and bond inflows, which is not observed in the data.

We conjecture that models without financial or other frictions are unlikely to be able to match the main empirical regularities of gross capital flows. Intuitively, in the absence of financial frictions productivity shocks do not lead naturally to a positive correlation between $C I F$ and $C O D$. For example, if a negative productivity shock during a crisis lowers the incentives for foreign agents to invest in the domestic economy, it should also probably increase the incentives for domestic agents to invest abroad.

In our view, the evidence is more consistent with models in which crises affect domestic and foreign agents asymmetrically. One natural source of asymmetry is asymmetric information. For example, Brennan and Cao (1997) and Tille and Van Wincoop (2008) argue that a retrenchment during crises can take place if foreign agents are less informed than domestic agents about the return of domestic assets, and crises increase this information asymmetry. ${ }^{19}$ Shocks to risk aversion can also lead to retrenchments during crises if agents consider foreign assets as riskier than domestic ones. This happens when, for example, assets are denominated in domestic currency and the nominal exchange rate is volatile. Milesi-Ferreti and Tille (2010) claim that risk aversion might have been the driver of the retrenchment in flows observed during the 2008 global financial crisis. Broner, Lorenzoni, and Schmukler (forthcoming) show evidence consistent with increases in risk aversion playing an important role during crises in middleincome countries.

Another source of asymmetry between domestic and foreign agents is sovereign risk. For example, Broner, Martin, and Ventura (2010) show that if domestic agents are less likely to be defaulted on than foreign agents, foreigners have an incentive to sell domestic assets to domestic agents in secondary markets, naturally leading to a retrenchment when the risk of default rises.

\footnotetext{
${ }^{19}$ See also Dvorak (2003), who emphasizes information asymmetry both between and within countries.
} 
More generally, models in which crises are associated with a relative deterioration of foreigners' property rights are likely to predict a retrenchment during crises.

Furthermore, a tightening of domestic financial constraints during crises can lead to a retrenchment as a result of deleveraging. However, in the absence of frictions that specifically affect international asset trade, this retrenchment should not take place for all flow types. In particular, while domestic agents might find it more difficult to borrow, there should be an increase in sales (or fire sales) of domestic firms to foreigners. This seems inconsistent with our finding that direct investment inflows also fall during crises. Overall, the behavior of gross capital flows suggests that fire sales are not a quantitatively important determinant of aggregate capital flows during crises. ${ }^{20}$

\section{Conclusions}

This paper provides a number of new stylized facts on the dynamic behavior of gross capital flows by domestic and foreign agents. The main results are as follows. (i) Gross capital flows are large and volatile, both in absolute terms and relative to the size and the volatility of net capital flows. This pattern is stronger in the 2000s than in the 1970s. This is because as the volatility of gross capital flows has increased, so has the positive correlation between gross capital inflows and outflows. (ii) Gross capital flows are pro-cyclical. Both gross capital inflows and outflows increase during expansions and decrease during economic downturns. During crises, total gross capital flows collapse as investors retrench from foreign markets. (iii) These retrenchments occur during both domestic and global crises, although those that take place

\footnotetext{
${ }^{20}$ Of course, this does not mean that fire sales have not taken place for some types of assets during particular episodes. See, for example, Krugman (1998), Aguiar and Gopinath (2005), Baker, Foley, and Wurgler (2009), and Acharya, Shin, and Yorulmazer (2010). In addition, despite the reduction in dollar terms, the quantity of assets purchased by foreigners might not actually decrease during crises due to the reduction in asset prices.
} 
during global crises are stronger. Also, these retrenchments happen during banking, currency, and debt crises. (iv) The retrenchments during crises take place for every type of gross capital flows, including direct investments, other investments, portfolio debt, and portfolio equity. The behavior of reserves differs across income groups, playing an important role in middle-income countries and none in high-income ones.

The stylized facts we document in this paper shed light on the sources of fluctuations of international capital flows. In our view, the evidence is more consistent with models in which crises affect domestic and foreign agents asymmetrically, as would be the case under the presence of sovereign risk or asymmetric information. But regardless of our own interpretation, the evidence provides a new set of empirical moments that will help judge the relevance of existing and future theories.

There are at least two directions in which the analysis could be usefully extended. First, it would be informative to decompose the changes in capital flows into changes in asset prices and changes in quantities. This would be particularly useful to gauge the potential size of fire sales. Second, it would be interesting to combine the data on capital flows with data on physical investment. This would provide a more complete description of the changes in the portfolios of domestic and foreign agents during crises. 


\section{Acknowledgements}

We received valuable comments from Andrew Abel, Enrique Alberola, Yan Bai (discussant), Mark Bills (editor), Eduardo Fernández-Arias, Marvin Goodfriend, Iikka Korhonen, Philip Lane, Andrew Powell, Carmen Reinhart, Luis Servén, Gianluca Violante (editor), Frank Warnock, and participants at presentations held at the AEA Annual Meetings, the Bank of Korea, the Bank of Spain, the Carnegie-NYU-Rochester Conference on Public Policy, CREI, the LACEA Annual Meetings, the NIPFP-DEA Workshop on Capital Flows, the Paris School of Economics, the Reserve Bank of India, the SED Annual Meetings, Universidad Torcuato Di Tella, the World Bank, and the XVIII Workshop on International Economics and Finance. We are especially grateful to Francisco Ceballos for outstanding research assistance. We also thank Leandro Brufman, Laura Fernández, Ana Maria Gazmuri, Lucas Núñez, Virginia Poggio, and Matías Vieyra, who helped us at early stages of the paper. Broner thanks the Spanish Ministry of Science and Innovation, the Generalitat de Catalunya, and the European Research Council (FP7/2007-2013, grant 263846) for financial support. This paper was partly written while he was visiting the Bank of Spain. Schmukler thanks the World Bank Development Economics Research Group and Knowledge for Change (KCP) Program for financial support. 


\section{References}

Acharya, V., Shin, H., Yorulmazer, T., 2010. Crisis Resolution and Bank Liquidity. Review of Financial Studies 24 (6), 2166-2205.

Aguiar, M., Gopinath, G., 2005. Fire-Sale Foreign Direct Investment and Liquidity Crises. Review of Economics and Statistics 87 (3), 439-452.

Albuquerque, R., Bauer, G., Schneider, M., 2007. International Equity Flows and Returns: A Quantitative Equilibrium Approach. Review of Economic Studies 74, 1-30.

Alfaro, L., Kanczuk, F., 2009. Optimal Reserve Management and Sovereign Debt. Journal of International Economics 77(1), 23-36.

Baker, M., Foley, F., Wurgler, J., 2009. Multinational as Arbitrageurs: The Effect of Stock Market Valuations on Foreign Direct Investment. Review of Financial Studies 22 (1), 337-369.

Bianchi, J., Hatchondo, J. C., Martinez, L., 2012. International Reserves and Rollover Risk. University of Wisconsin. Mimeo.

Brennan, M., Cao, H., 1997. International Portfolio Investment Flows. Journal of Finance 52, 1851-1880.

Broner, F., Didier, T., Erce, A., Schmukler, S., 2010. Gross Capital Flows: Dynamics and Crises. Bank of Spain Working Paper 1039, World Bank Policy Research Working Paper 5768, and CEPR Discussion Paper No. 8591.

Broner, F., Lorenzoni, G., Schmukler, S., forthcoming. Why Do Emerging Economies Borrow Short Term? Journal of the European Economic Association.

Broner, F., Martin, A., Ventura, J., 2010. Sovereign Risk and Secondary Markets. American Economic Review 100, 1523-55.

Broner, F., Rigobon, R., 2006. Why are Capital Flows so Much More Volatile in Emerging than in Developed Countries? In: Caballero, R., Calderón, C., Céspedes, L. (Eds.), External Vulnerability and Preventive Policies, Central Bank of Chile, pp. 15-40.

Calvo, G., 1998. Capital Flows and Capital-Markets Crises: The Simple Economics of Sudden Stops. Journal of Applied Economics 1 (1), 35-54.

Calvo, G., 2011. On Capital Inflows, Liquidity and Bubbles. Columbia University. Mimeo.

Calvo, G., Izquierdo, A., Mejía, L., 2008. Systemic Sudden Stop: The Relevance of Balance-Sheet Effects and Financial Integration. NBER Working Paper No. 14026.

Calderon, C., Kubota, M., forthcoming. Sudden Stops: Are Global and Local Investors Alike? Journal of International Economics.

Cavallo, E., Frankel, J., 2008. Does Openness to Trade Make Countries More Vulnerable to Sudden Stops, or Less? Using Gravity to Establish Causality. Journal of International Money and Finance 27, 1430-1452.

Choe, H., Kho, B., Stulz, R., 2005. Do Domestic Investors Have an Edge? The Trading Experience of Foreign Investors in Korea. Review of Financial Studies 18 (3), 795-829.

Coeurdacier, N., Kollmann, R., Martin , P., 2010. International Portfolios, Capital Accumulation and Foreign Assets Dynamics. Journal of International Economics 80, 100-112.

Cowan, K., De Gregorio, J., Micco, A., Neilson, C., 2008. Financial Diversification, Sudden Stops, and Sudden Starts. In: Cowan, K., Edwards, S., Valdés, R., Loayza, N. (Eds.), Current Account and External Finance, Central Bank of Chile, pp. 159-194.

Devereux, M., 2007. Financial Globalization and Emerging Market Portfolios. Monetary and Economic Studies 25, 101-30. 
Devereux, M., Sutherland, A., 2010. Valuation Effects and the Dynamics of Net External Assets. Journal of International Economics 80, 129-143.

Devereux, M., Sutherland, A., 2011. Country Portfolios in Open Economy Macro Models. Journal of the European Economic Association 9 (2), 337-369.

Dornbusch, R., Goldfajn, I., Valdés, R., 1995. Currency Crises and Collapses. Brooking Papers on Economic Activity 1995 (2), 219-270.

Durdu, C., Mendoza, E., Terrones, M., 2009. Precautionary Demand for Foreign Assets in Sudden Stop Economies: An Assessment of the New Mercantilism. Journal of Development Economics 89(2), 194-209.

Dvorak, T., 2003. Gross Capital Flows and Asymmetric Information. Journal of International Money and Finance 22, 835-864.

Evans, M., Hnatkovska, V., 2005. International Capital Flows Returns and World Financial Integration. NBER Working Paper No. 11701.

Faucette, J., Rothenberg, A., Warnock, F., 2005. Outflows-Induced Sudden Stops. Journal of Policy Reform 8, 119-29.

Forbes, K., Warnock, F., forthcoming. Capital Flow Waves: Surges, Stops, Flight and Retrenchment. Journal of International Economics.

Frankel, J., Rose, A., 1996. Currency Crashes in Emerging Markets: An Empirical Treatment. Journal of International Economics 41, 351-66.

Frankel, J., Schmukler, S., 1996. Country Fund Discounts and the Mexican Crisis of December 1994: Did Local Residents Turn Pessimistic Before International Investors? Open Economies Review 7, 511-34.

Gourinchas, P., Rey, H., 2007a. From World Banker to World Venture Capitalist: U.S. External Adjustment and the Exorbitant Privilege. In: Clarida, R. (Ed.), G7 Current Account Imbalances: Sustainability and Adjustment, NBER, 11-66.

Gourinchas, P., Rey, H., 2007b. International Financial Adjustment. Journal of Political Economy 115, 665-703.

Hnatkovska, V., 2010. Home Bias and High Turnover: Dynamic Portfolio Choice with Incomplete Markets. Journal of International Economics 80, 113-28.

Janus, T., Riera-Crichton, D., 2009. International Gross Capital Flows: A New Measure and Application to a Global Panel. Santa Cruz Center for International Economics (SCCIE) Working Paper 09-08.

Jeanne, O., Ranciere, R., 2011. The Optimal Level of International Reserves for Emerging Market Countries: A New Formula and Some Applications. Economic Journal 121(555), 905-930.

Kaminsky, G., Lizondo, S., Reinhart, C., 1998. Leading Indicators of Currency Crises. IMF Staff Papers 45, 1-48.

Kim, W., Wei, S., 2002. Foreign Portfolio Investors Before and During a Crisis. Journal of International Economics 56, 77-96.

Kraay, A., Loayza, N., Servén, L., Ventura, J., 2005. Country Portfolios. Journal of the European Economic Association 3, 914-45.

Kraay, A., Ventura, J., 2000. Current Account in Debtors and Creditors Countries. Quarterly Journal of Economics 115, 665-703.

Krugman, P., 1998. Fire-Sale FDI. Princeton University Notes.

Laeven, L., Valencia, F., 2008. Systemic Banking Crises: A New Database. IMF Working Paper 224. 
Lane, P., Milesi-Ferretti, G., 2001 Long-Term Capital Movements. NBER Macroeconomics Annual 2000, 73-116. NBER.

Lane, P., Milesi-Ferretti, G., 2007. The External Wealth of Nations Mark II: Revised and Extended Estimates of Foreign Assets and Liabilities, 1970-2004. Journal of International Economics 73, 223-50.

Levchenko, A., Mauro, P., 2007. Do Some Forms of Financial Flows Protect from Sudden Stops? World Bank Economic Review 21, 389-411.

Mendoza, E., 2010. Sudden Stops, Financial Crises, and Leverage. American Economic Review 100 (5), 1941-1966.

Milesi-Ferretti, G., Tille, C., 2010. The Great Retrenchment: International Capital Flows during the Global Financial Crisis. Economic Policy 66, 285-330.

Obstfeld, M., 2012. Financial Flows, Financial Crises, and Global Imbalances. Journal of International Money and Finance 31 (3), 469-480.

Pavlova, A., Rigobon, R., 2010. An Asset-Pricing View of External Adjustment. Journal of International Economics 80, 144-156.

Pavlova, A., Rigobon, R., forthcoming. International Macro-Finance. Handbook of Financial Globalization, Elsevier.

Powell, A., Ratha, D., Mohapatra, S., 2002. Capital Inflows and Capital Outflows: Measurement, Determinants, Consequences. Business School Working Paper, Universidad Torcuato Di Tella.

Reinhart, C., Rogoff, K., 2009. This Time is Different: Eight Centuries of Financial Folly. Princeton University Press.

Rothenberg, A., Warnock, F., 2011. Sudden Flight and True Sudden Stops. Review of International Economics 19 (3), 509-524.

Tille, C., van Wincoop, E., 2008. International Capital Flows. Journal of International Economics 80, 157-75.

Tille, C., van Wincoop, E., 2010. International Capital Flows under Dispersed Information: Theory and Evidence. NBER Working Paper No. 14390. 
Figure 1

Capital Flows in Selected Countries

High-Income Countries

Japan

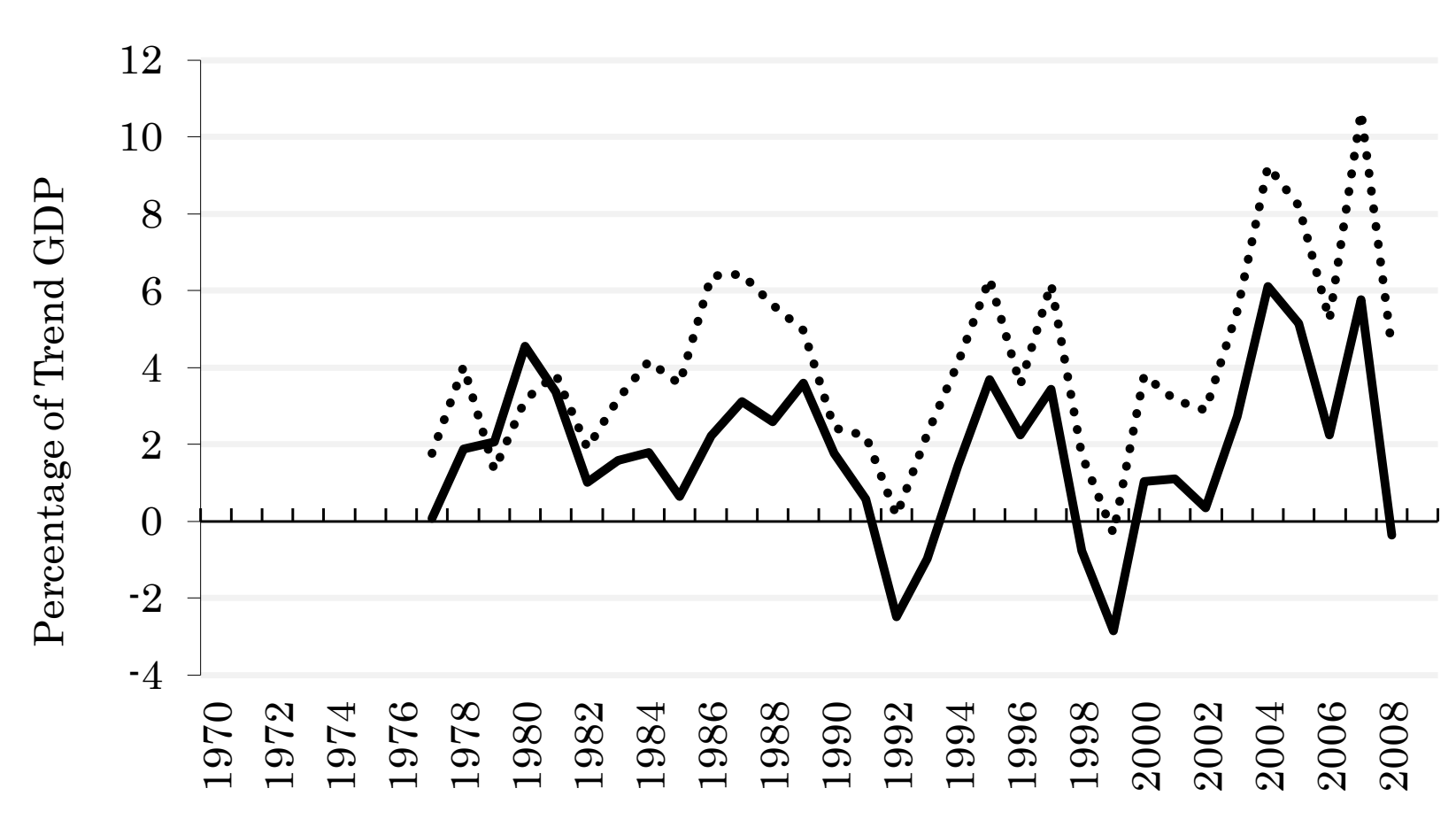

Argentina

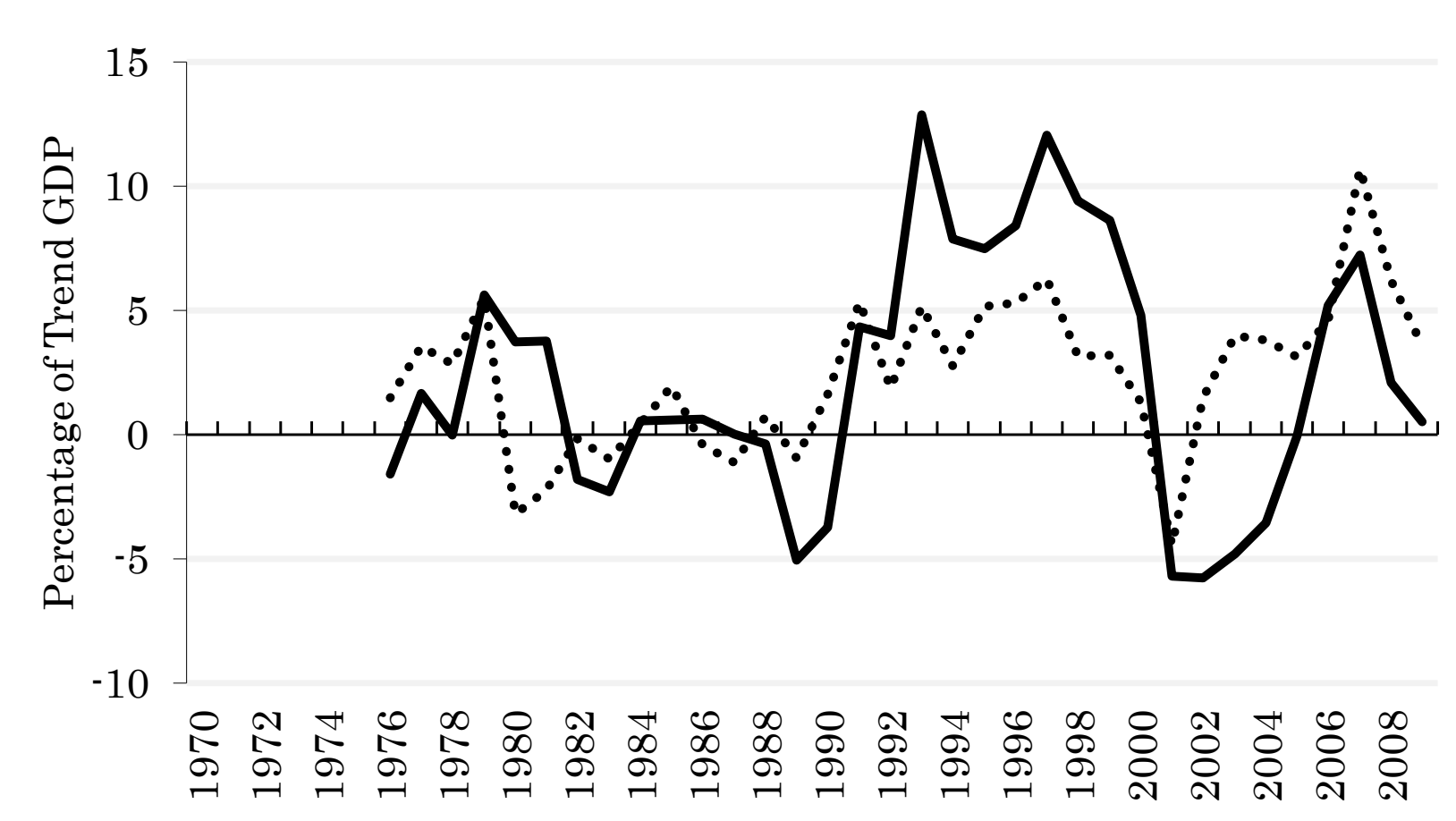

China

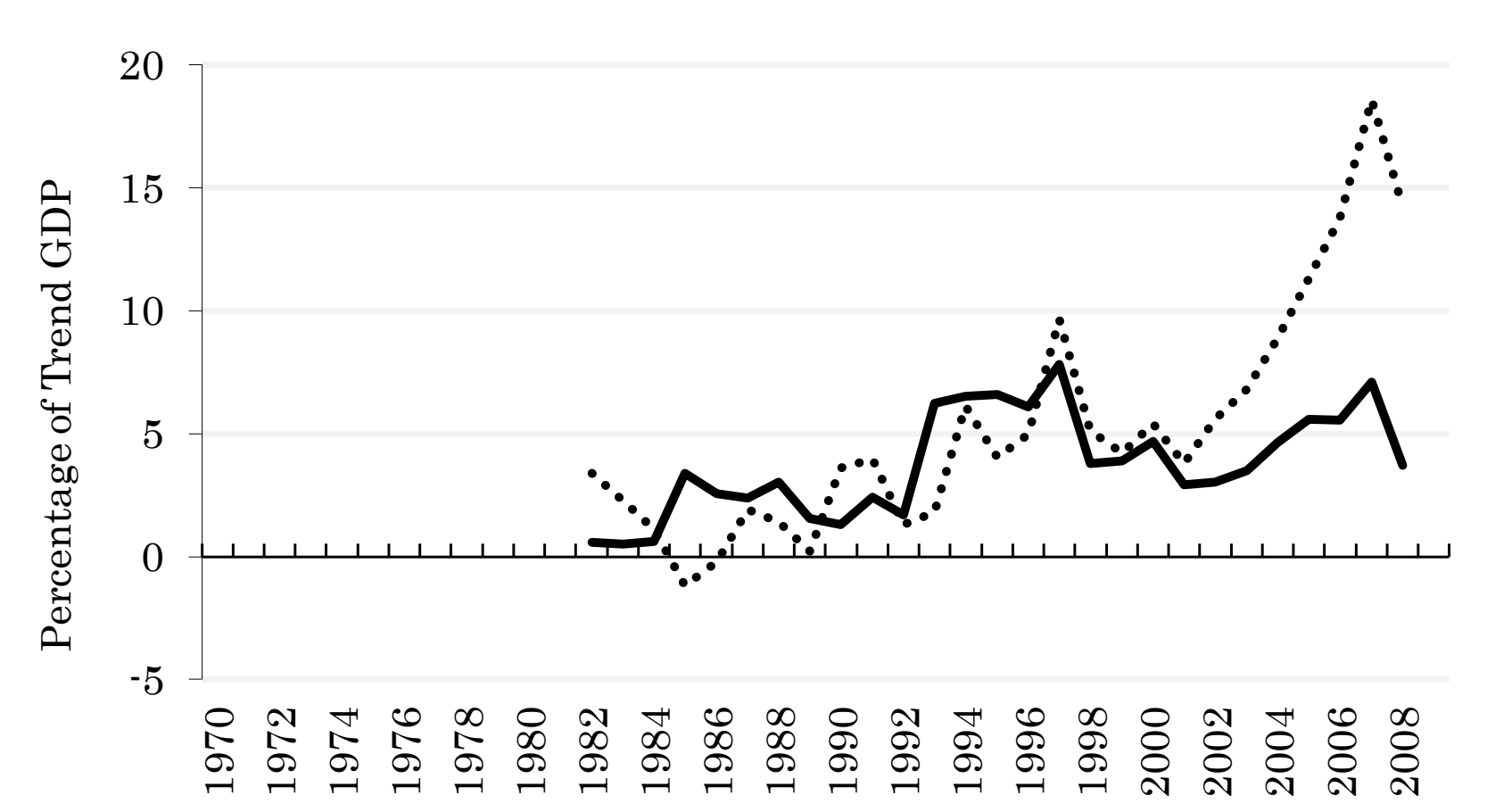

Spain

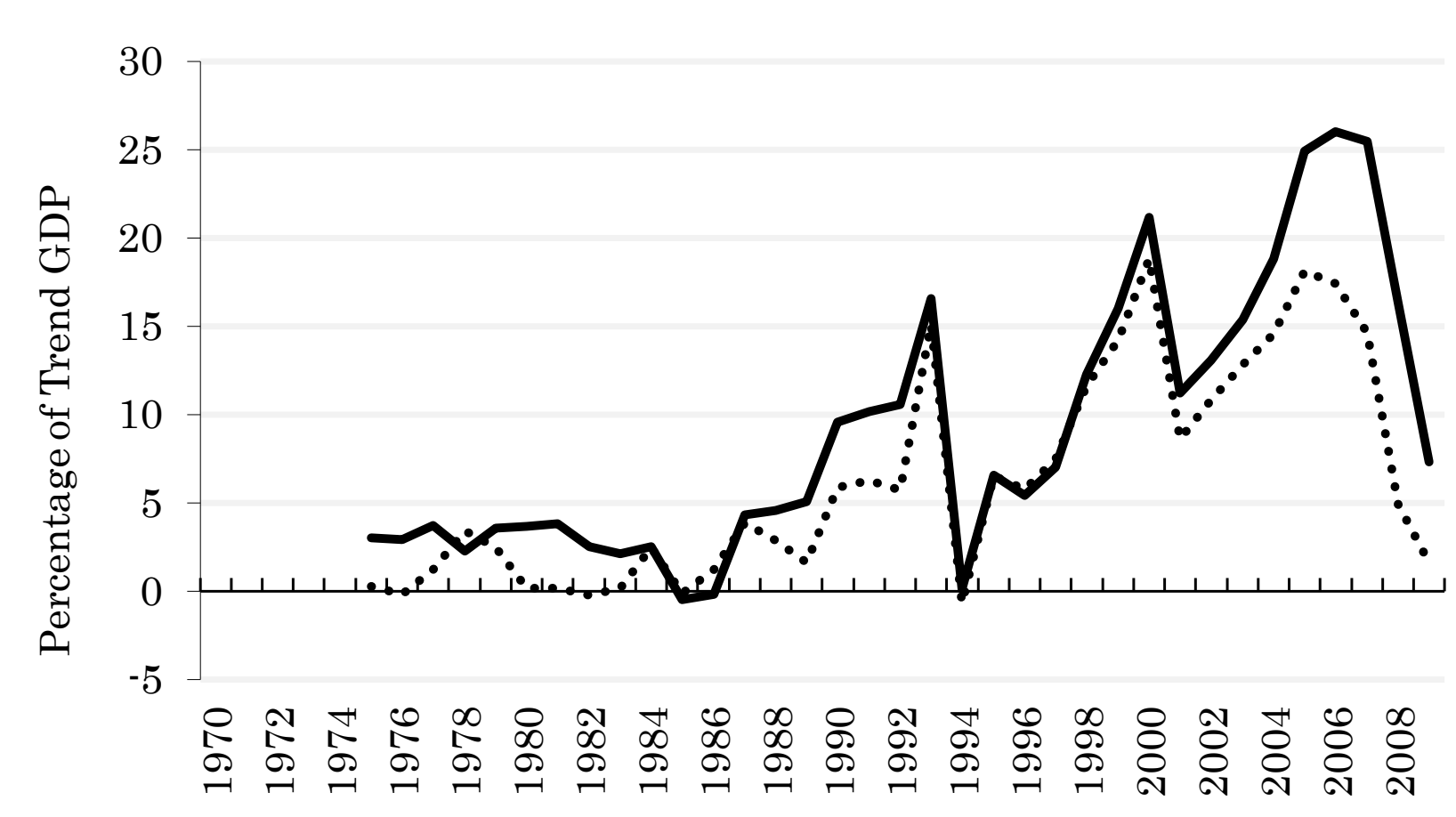

Upper-Middle-Income Countries

Brazil

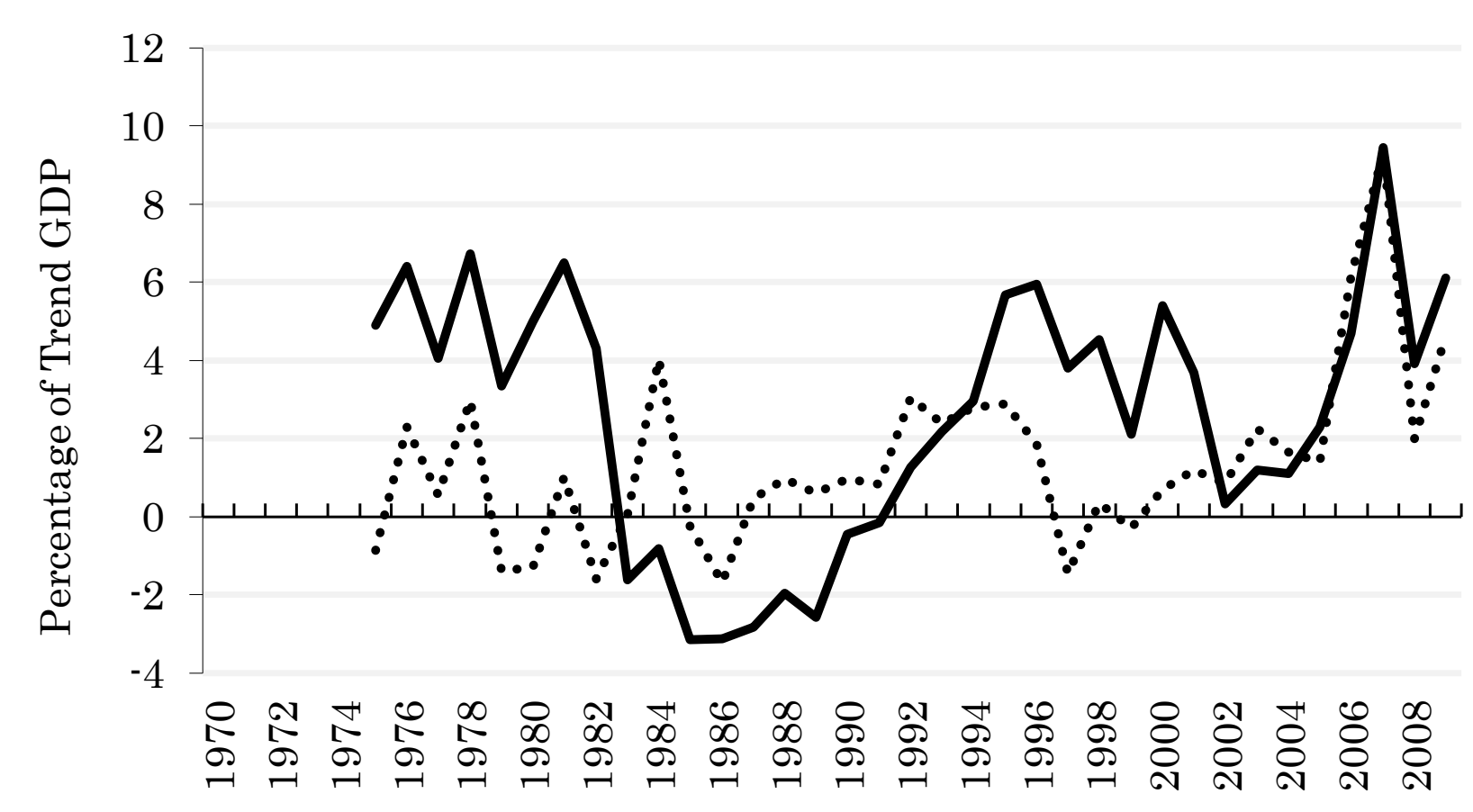

Lower-Middle-Income Countries

$$
\text { India }
$$

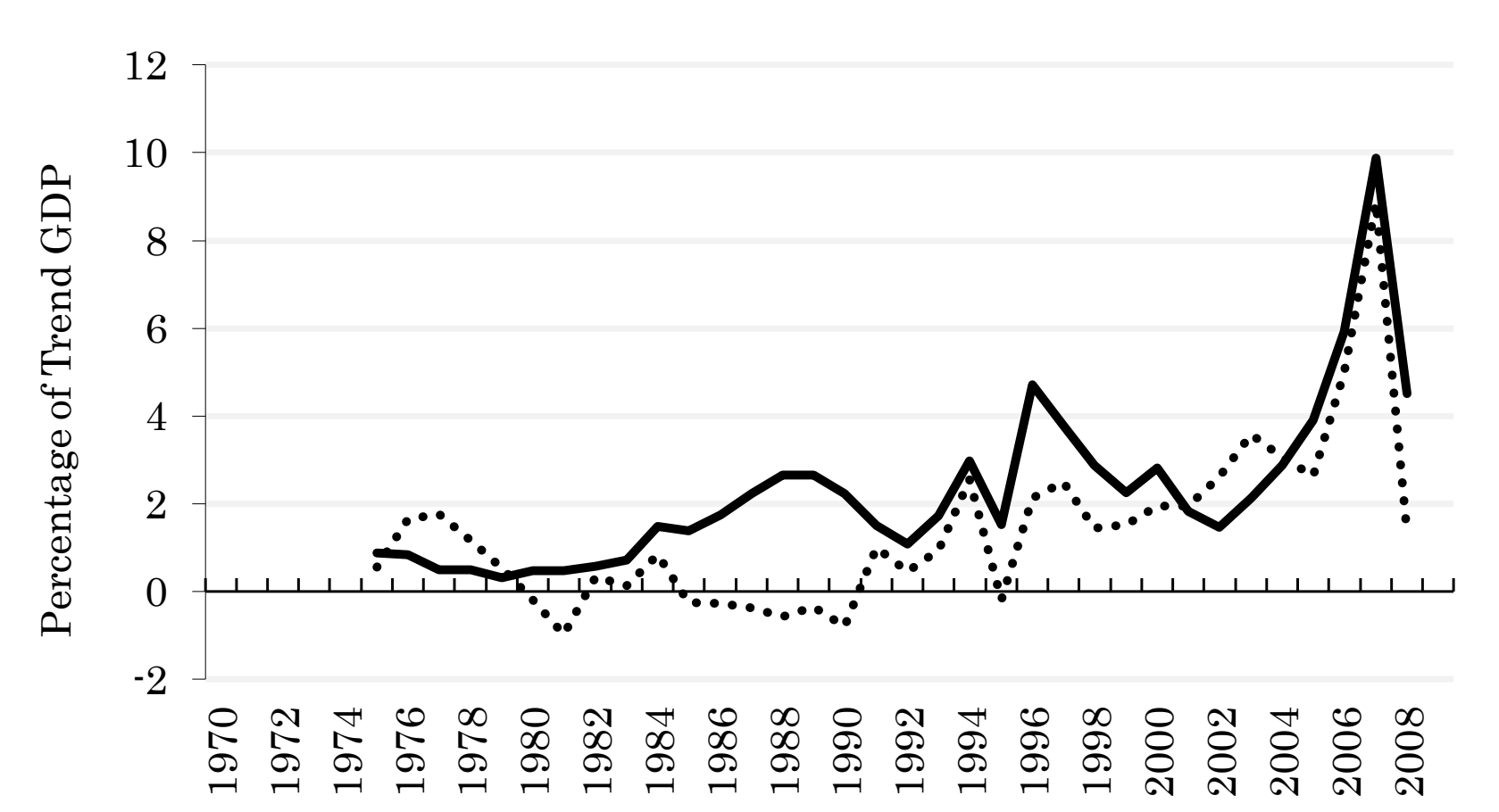

United States

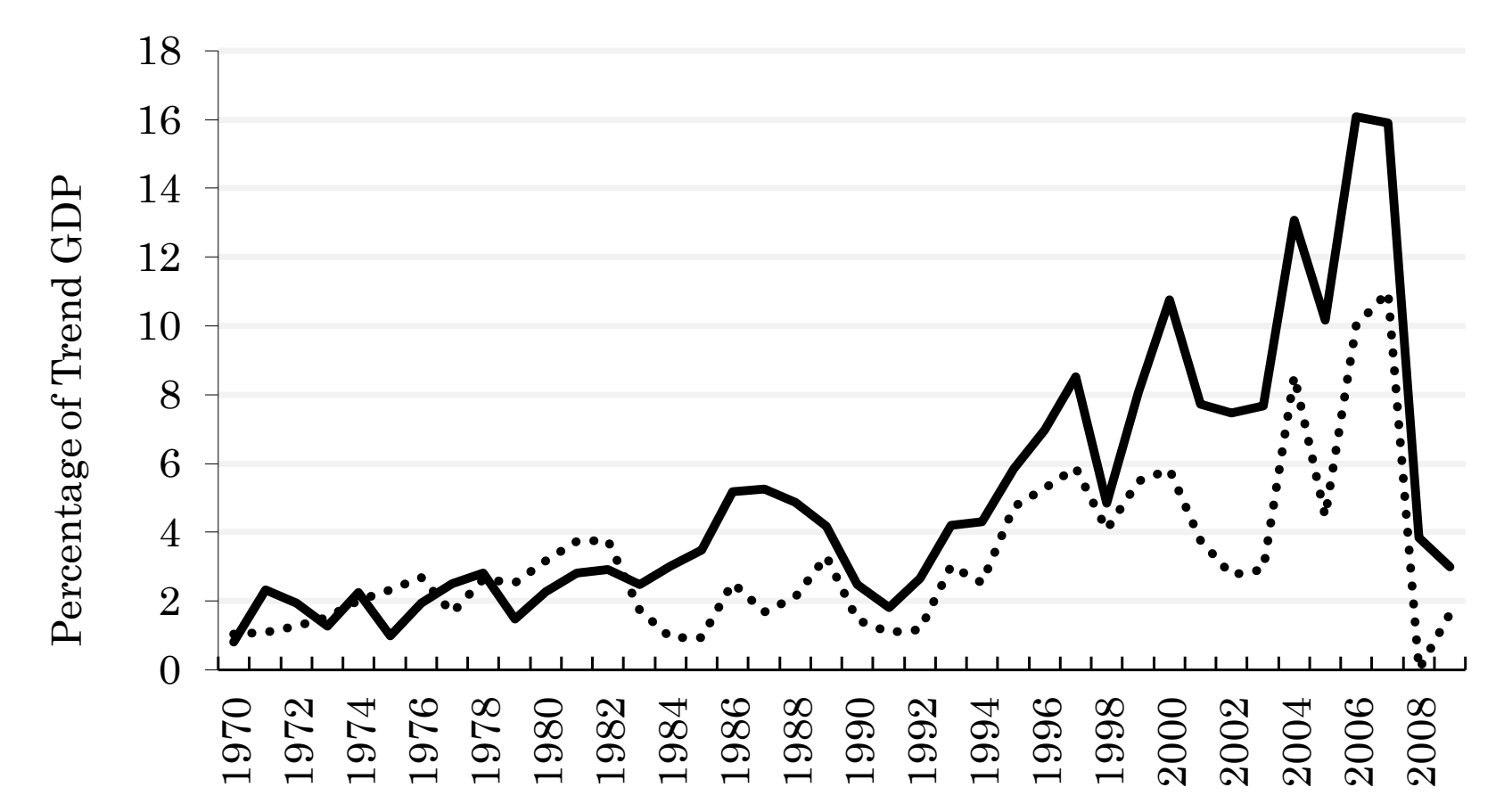

Turkey

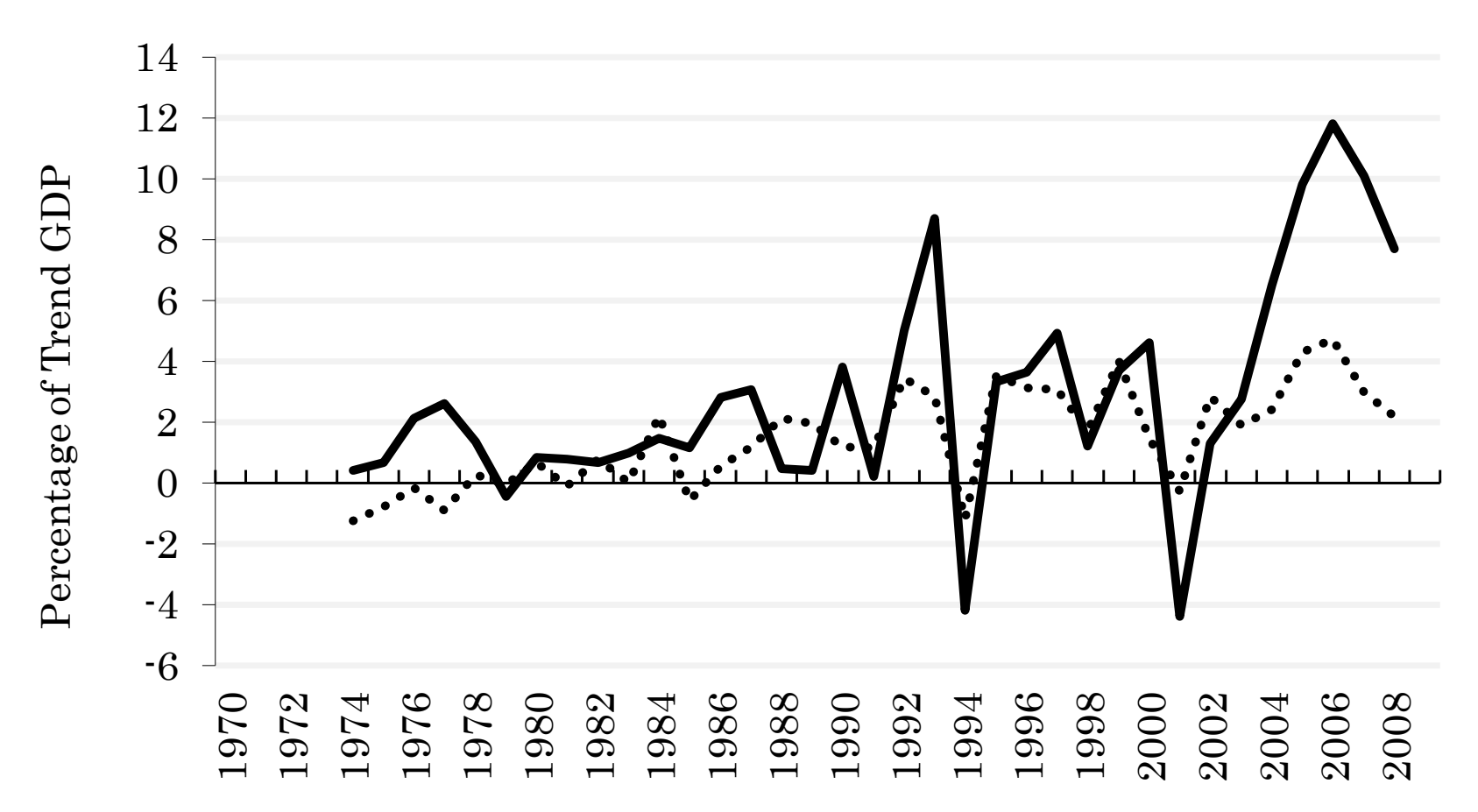

Thailand

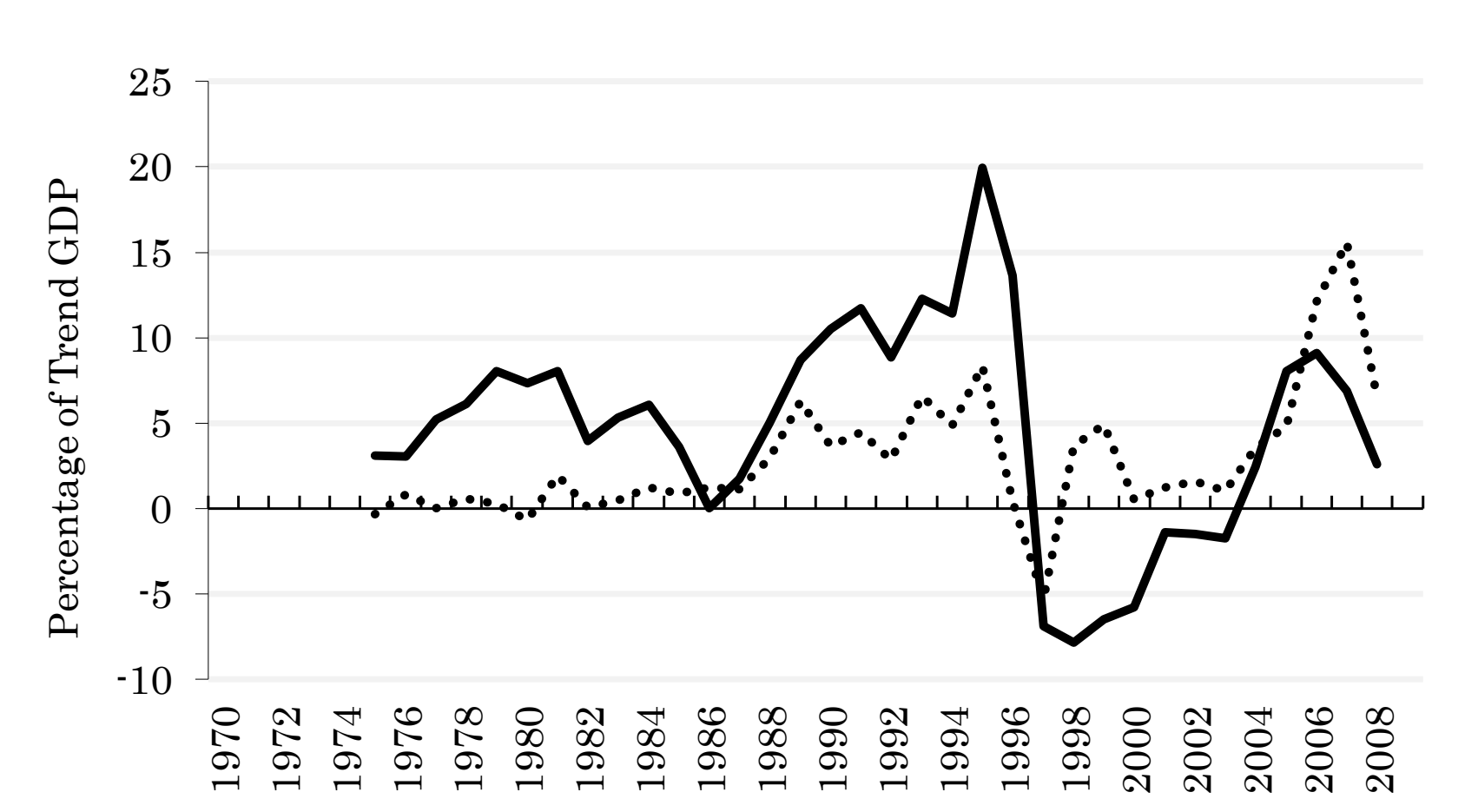

—Capital Inflows by Foreign Agents (CIF)

… Capital Outflows by Domestic Agents (COD) 
Figure 2

Joint Distribution of Capital Flows

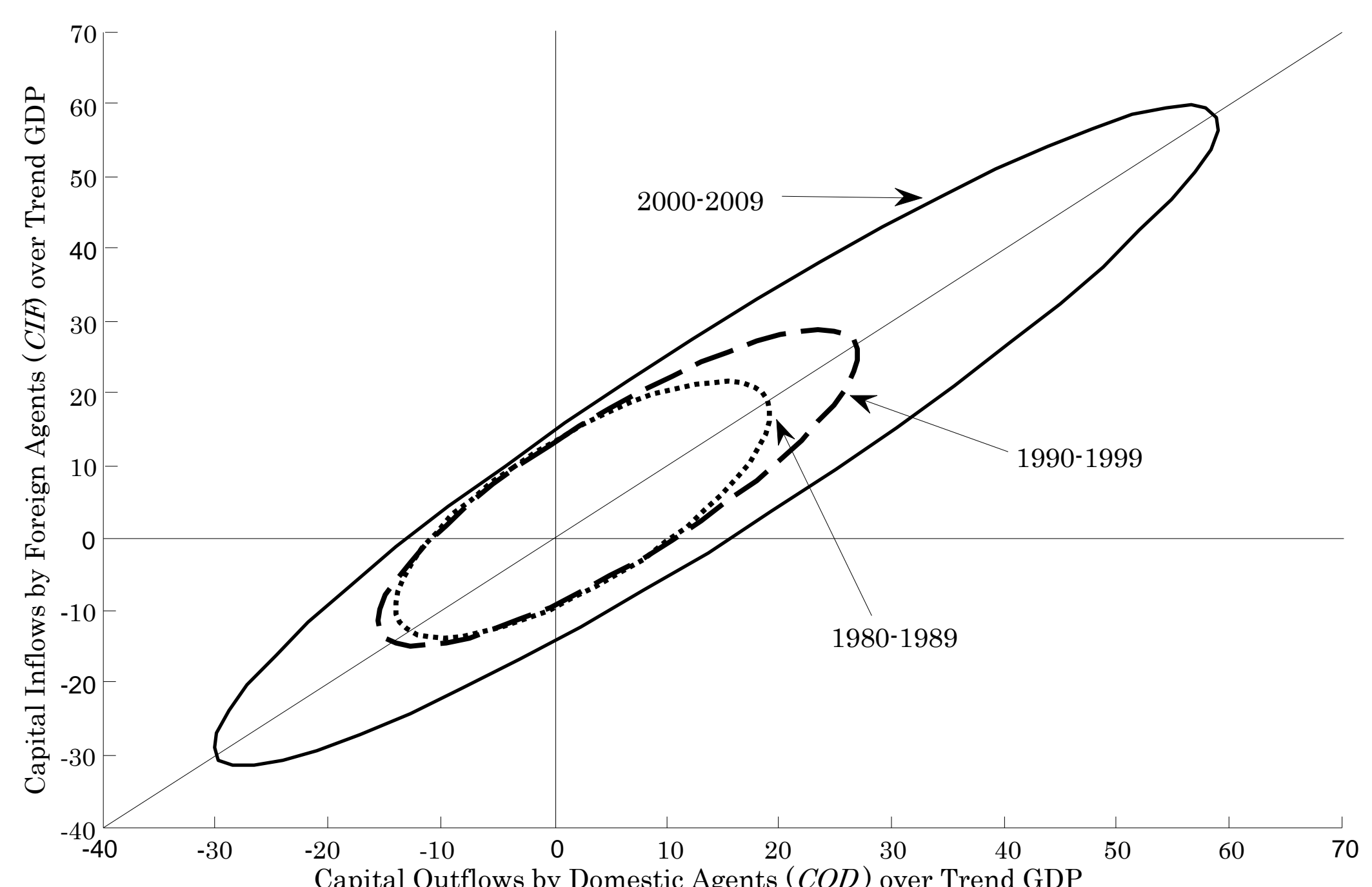

This figure shows the ellipses that represent the joint distribution of capital flows by foreign and domestic agents $(C I F$ and $C O D$ ). We report one ellipsis per decade. Each ellipsis reflects 103 points and each point represents the average for that decade for each country in our sample. Capital flows are scaled by trend GDP. 
Figure 3

Capital Flows around Crises

All Countries

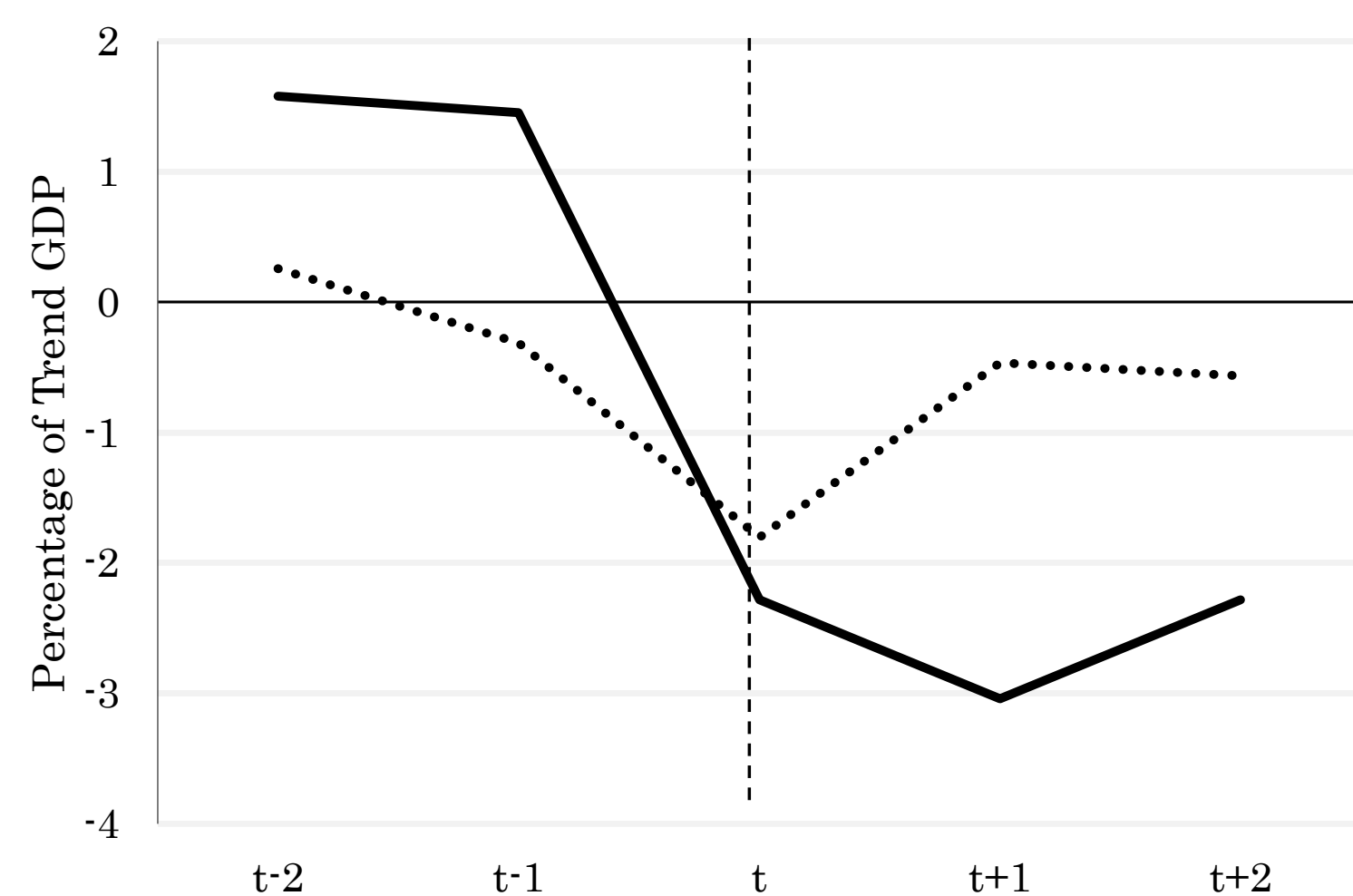

Upper-Middle-Income Countries

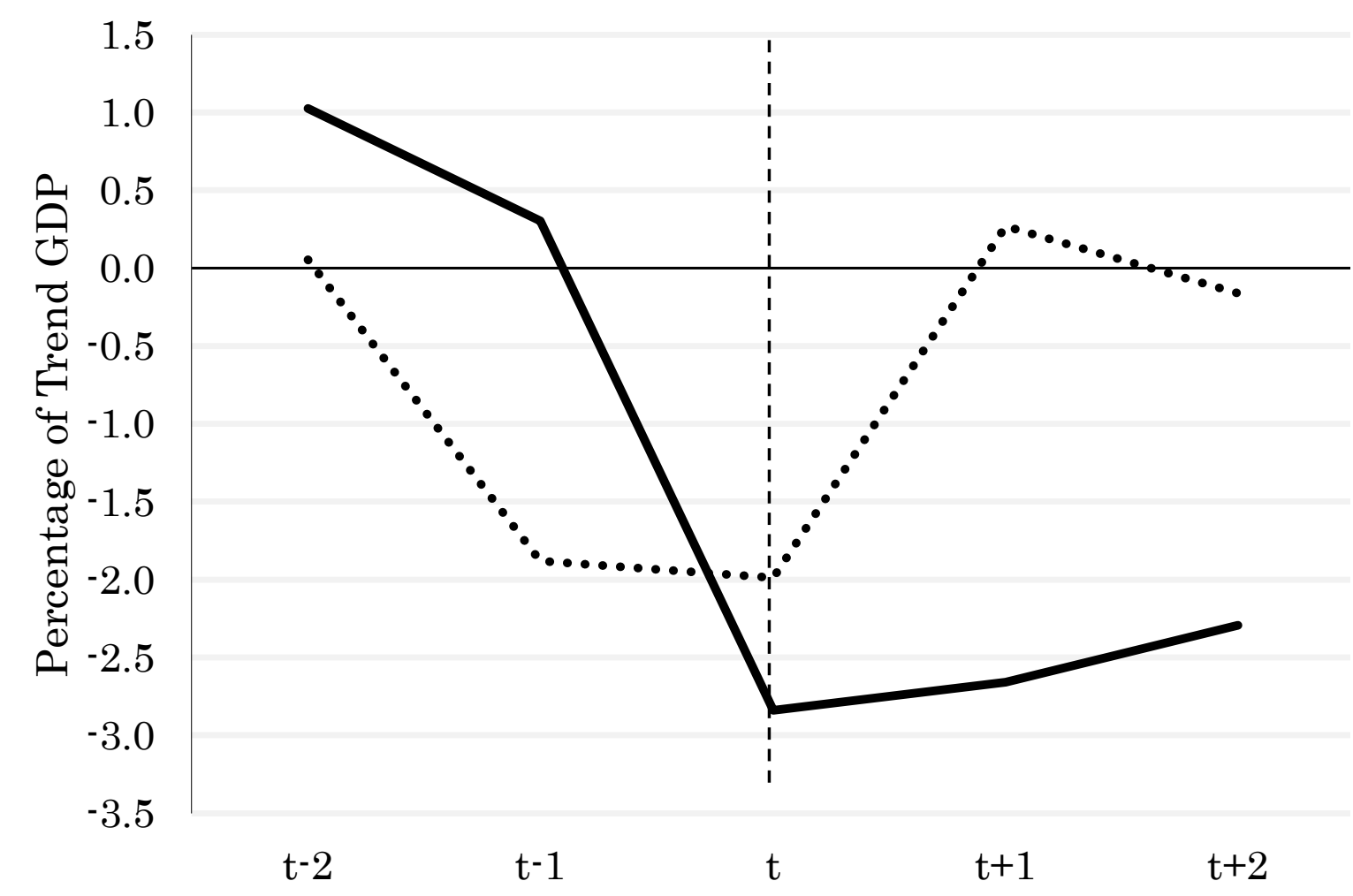

High-Income Countries

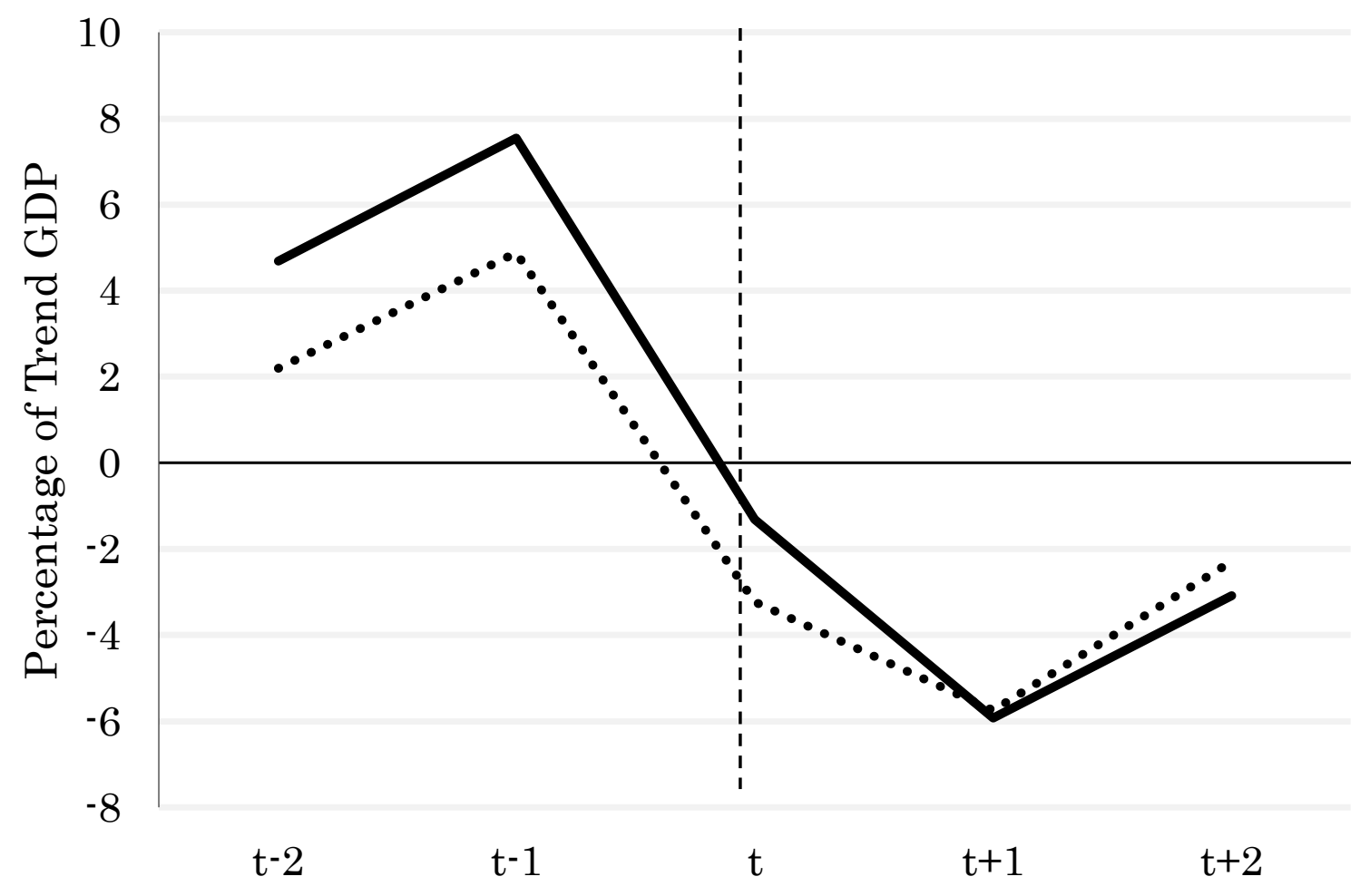

Lower-Middle-Income Countries

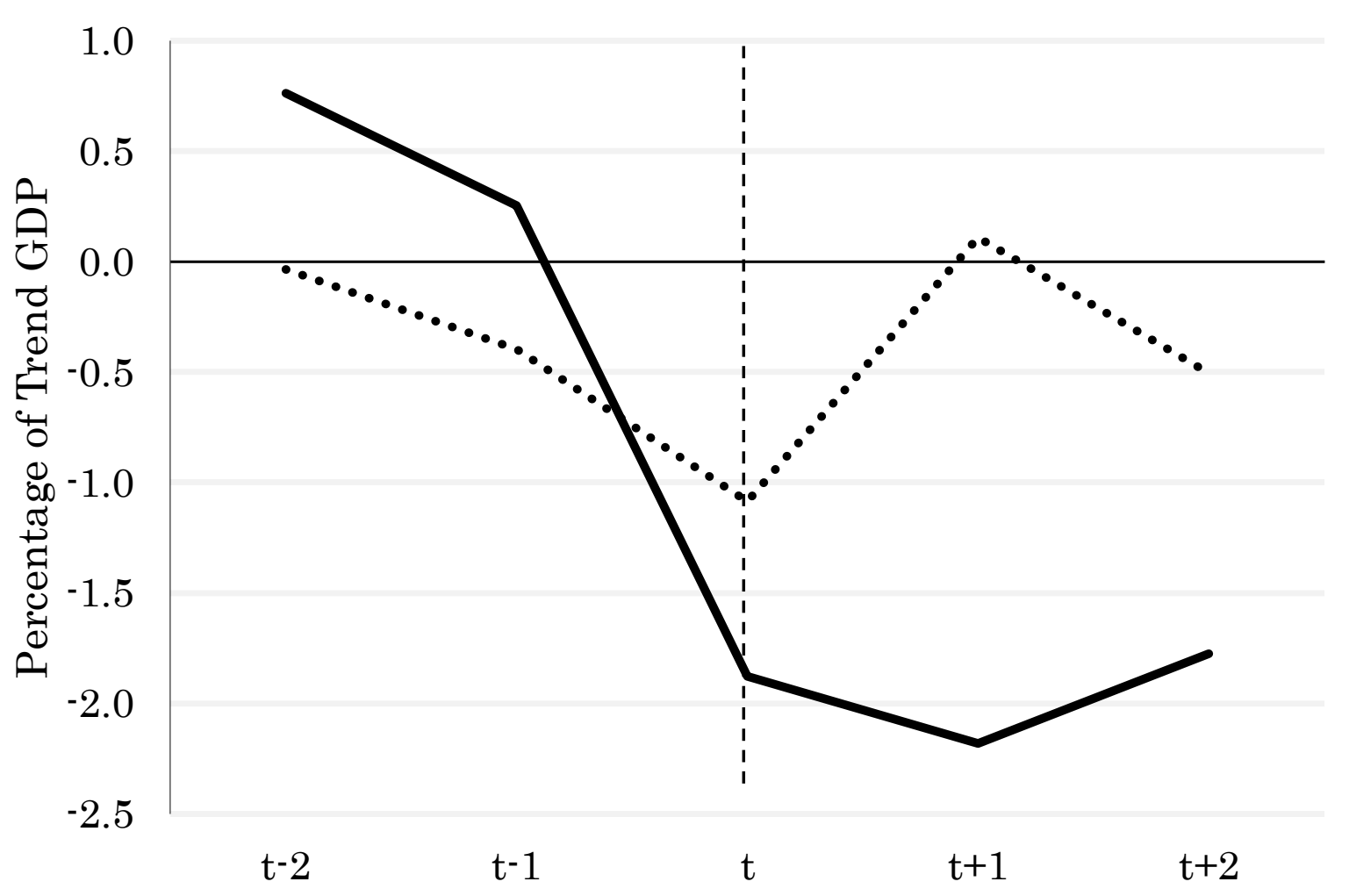
outflows by domestic agents (COD) in five-year windows around crisis periods. The figure shows the economic importance of the coefficients obtained in the regressions reported in Tables 5 and 6 . In those regressions, capital flows are first normalized by trend GDP and then standardized by de-meaning and dividing by the standard deviation at the country level. We calculate the numbers for this figure as the product of the estimated coefficients and the median one standard deviation of the non-standardized value of the dependent variable across countries with at least one crisis during the period under analysis. The figure reports the results for all of the countries in the sample, as well as separately for high-income, upper-middle-income, and lower-middle-income countries. The sample period is from 1970 to 2009. 
Table 1

Capital Flows: Summary Statistics

\begin{tabular}{|c|c|c|c|c|c|c|c|c|}
\hline & \multicolumn{2}{|c|}{ All Countries } & \multicolumn{2}{|c|}{$\begin{array}{c}\text { High-Income } \\
\text { Countries }\end{array}$} & \multicolumn{2}{|c|}{$\begin{array}{c}\text { Upper-Middle-Income } \\
\text { Countries }\end{array}$} & \multicolumn{2}{|c|}{$\begin{array}{c}\text { Lower-Middle-Income } \\
\text { Countries }\end{array}$} \\
\hline & $\begin{array}{l}\text { Median } \\
\text { Average } \\
\end{array}$ & $\begin{array}{l}\text { Median } \\
\text { Std. Dev. }\end{array}$ & $\begin{array}{l}\text { Median } \\
\text { Average }\end{array}$ & $\begin{array}{l}\text { Median } \\
\text { Std. Dev. }\end{array}$ & $\begin{array}{l}\text { Median } \\
\text { Average }\end{array}$ & $\begin{array}{l}\text { Median } \\
\text { Std. Dev. }\end{array}$ & $\begin{array}{l}\text { Median } \\
\text { Average }\end{array}$ & $\begin{array}{l}\text { Median } \\
\text { Std. Dev. }\end{array}$ \\
\hline \multicolumn{9}{|c|}{ Net Capital Flows $(C I F-C O D)$} \\
\hline All Sample & 1.39 & 5.07 & 0.64 & 3.92 & 1.29 & 5.62 & 2.08 & 5.51 \\
\hline $1970 \mathrm{~s}$ & 2.06 & 3.01 & 1.64 & 2.41 & 3.37 & 3.94 & 3.54 & 3.09 \\
\hline $1980 \mathrm{~s}$ & 1.59 & 3.93 & 1.42 & 2.71 & 0.39 & 5.56 & 2.71 & 4.11 \\
\hline $1990 \mathrm{~s}$ & 0.98 & 3.68 & 0.87 & 2.79 & 0.82 & 4.23 & 1.28 & 4.18 \\
\hline $2000 \mathrm{~s}$ & 1.09 & 3.97 & -0.18 & 3.60 & 1.90 & 3.94 & 0.56 & 4.37 \\
\hline \multicolumn{9}{|c|}{ Total Gross Capital Flows $(C I F+C O D)$} \\
\hline All Sample & 11.31 & 10.54 & 17.67 & 15.49 & 9.31 & 10.01 & 6.97 & 7.17 \\
\hline $1970 \mathrm{~s}$ & 7.78 & 3.39 & 9.50 & 3.62 & 7.01 & 5.27 & 7.92 & 2.75 \\
\hline $1980 \mathrm{~s}$ & 5.83 & 5.20 & 9.10 & 6.16 & 1.96 & 5.95 & 4.86 & 3.90 \\
\hline $1990 \mathrm{~s}$ & 8.94 & 7.21 & 13.56 & 9.39 & 7.80 & 5.60 & 7.21 & 5.56 \\
\hline $2000 \mathrm{~s}$ & 15.15 & 9.34 & 32.65 & 16.70 & 15.06 & 8.48 & 8.41 & 6.21 \\
\hline \multicolumn{9}{|c|}{ Capital Inflows by Foreign Agents $(C I F)$} \\
\hline All Sample & 6.21 & 6.39 & 8.89 & 7.81 & 4.83 & 6.06 & 4.07 & 5.21 \\
\hline $1970 \mathrm{~s}$ & 5.10 & 2.56 & 4.73 & 2.66 & 5.08 & 3.07 & 5.62 & 2.29 \\
\hline $1980 \mathrm{~s}$ & 3.89 & 3.49 & 4.79 & 3.47 & 0.83 & 4.03 & 3.99 & 3.37 \\
\hline $1990 \mathrm{~s}$ & 4.97 & 4.58 & 7.00 & 5.54 & 3.96 & 4.12 & 4.43 & 4.16 \\
\hline $2000 \mathrm{~s}$ & 7.59 & 5.26 & 15.16 & 9.16 & 5.58 & 4.96 & 4.22 & 3.93 \\
\hline \multicolumn{9}{|c|}{ Capital Outflows by Domestic Agents (COD) } \\
\hline All Sample & 4.36 & 5.37 & 8.33 & 8.05 & 3.78 & 5.10 & 2.87 & 3.87 \\
\hline $1970 \mathrm{~s}$ & 2.52 & 2.16 & 3.43 & 2.29 & 3.34 & 2.96 & 2.07 & 1.77 \\
\hline $1980 \mathrm{~s}$ & 1.57 & 2.56 & 3.78 & 3.09 & 1.40 & 2.71 & 0.54 & 2.06 \\
\hline $1990 \mathrm{~s}$ & 3.75 & 3.65 & 6.56 & 5.32 & 2.80 & 3.32 & 2.54 & 3.03 \\
\hline $2000 \mathrm{~s}$ & 6.74 & 5.31 & 17.71 & 8.13 & 6.44 & 4.86 & 3.73 & 3.35 \\
\hline No. of Countries & \multicolumn{2}{|c|}{103} & \multicolumn{2}{|c|}{39} & \multicolumn{2}{|c|}{26} & \multicolumn{2}{|c|}{38} \\
\hline
\end{tabular}

This table shows the summary statistics of capital flows by both foreign and domestic agents (CIF and $C O D)$, net capital inflows $(C I F-C O D)$, and total gross capital flows $(C I F+C O D)$. Capital flows are scaled by trend GDP. The median value of country averages and of country standard deviations of capital flows are reported. The figure reports the results for all of the countries in the sample, as well as separately for high-income, upper-middle-income, and lower-middle-income countries. The sample period is from 1970 to 2009. 
Table 2

Correlation between Capital Flows

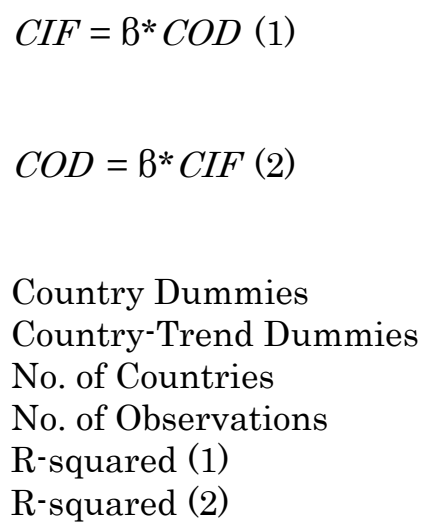

\begin{tabular}{|c|c|c|c|}
\hline \multicolumn{4}{|c|}{ All Countries } \\
\hline $1980 \mathrm{~s}$ & $1990 \mathrm{~s}$ & $2000 \mathrm{~s}$ & All Sample \\
\hline $\begin{array}{l}0.23 * * * \\
{[0.07]}\end{array}$ & $\begin{array}{l}0.46 * * * \\
{[0.06]}\end{array}$ & $\begin{array}{l}0.69 * * * \\
{[0.04]}\end{array}$ & $\begin{array}{l}0.51 * * * \\
{[0.04]}\end{array}$ \\
\hline $\begin{array}{l}0.26 * * * \\
{[0.08]}\end{array}$ & $\begin{array}{l}0.49 * * * \\
{[0.05]}\end{array}$ & $\begin{array}{l}0.81 * * * \\
{[0.04]}\end{array}$ & $\begin{array}{l}0.50 * * * \\
{[0.04]}\end{array}$ \\
\hline
\end{tabular}

$\begin{array}{rrrr}\text { Yes } & \text { Yes } & \text { Yes } & \text { Yes } \\ \text { Yes } & \text { Yes } & \text { Yes } & \text { Yes } \\ 83 & 103 & 101 & 103 \\ 791 & 937 & 923 & 3,052 \\ 0.45 & 0.48 & 0.69 & 0.42 \\ 0.28 & 0.43 & 0.68 & 0.43\end{array}$

High-Income Countries

\begin{tabular}{|c|c|c|c|}
\hline $1980 \mathrm{~s}$ & $1990 \mathrm{~s}$ & $2000 \mathrm{~s}$ & All Sample \\
\hline $\begin{array}{l}0.48 * * \\
{[0.20]}\end{array}$ & $\begin{array}{l}0.83 * * * \\
{[0.08]}\end{array}$ & $\begin{array}{l}0.93 * * * \\
{[0.04]}\end{array}$ & $\begin{array}{l}0.78 * * * \\
{[0.05]}\end{array}$ \\
\hline $\begin{array}{l}0.37 * * * \\
{[0.12]}\end{array}$ & $\begin{array}{l}0.68 * * * \\
{[0.06]}\end{array}$ & $\begin{array}{l}0.92 * * * \\
{[0.04]}\end{array}$ & $\begin{array}{l}0.75 * * * \\
{[0.05]}\end{array}$ \\
\hline
\end{tabular}

$\begin{array}{rrrr}\text { Yes } & \text { Yes } & \text { Yes } & \text { Yes } \\ \text { Yes } & \text { Yes } & \text { Yes } & \text { Yes } \\ 34 & 39 & 39 & 39 \\ 338 & 371 & 365 & 1,300 \\ 0.46 & 0.68 & 0.89 & 0.71 \\ 0.46 & 0.73 & 0.89 & 0.71\end{array}$

Upper-Middle-Income Countries

\begin{tabular}{|c|c|c|c|}
\hline $1980 \mathrm{~s}$ & $1990 \mathrm{~s}$ & $2000 \mathrm{~s}$ & All Sample \\
\hline $\begin{array}{r}0.28 \\
{[0.17]}\end{array}$ & $\begin{array}{l}0.23 * * * \\
{[0.08]}\end{array}$ & $\begin{array}{l}0.65 * * * \\
{[0.07]}\end{array}$ & $\begin{array}{l}0.44 * * * \\
{[0.07]}\end{array}$ \\
\hline $\begin{array}{r}0.25 \\
{[0.16]}\end{array}$ & $\begin{array}{l}0.36 * * * \\
{[0.11]}\end{array}$ & $\begin{array}{l}0.88 * * * \\
{[0.06]}\end{array}$ & $\begin{array}{r}0.45 \quad * * * \\
{[0.07]}\end{array}$ \\
\hline Yes & Yes & Yes & Yes \\
\hline Yes & Yes & Yes & Yes \\
\hline 20 & 26 & 25 & 26 \\
\hline 176 & 237 & 226 & 702 \\
\hline 0.45 & 0.40 & 0.70 & 0.36 \\
\hline 0.33 & 0.23 & 0.67 & 0.35 \\
\hline
\end{tabular}

Lower-Middle-Income Countries

\begin{tabular}{|c|c|c|c|}
\hline $1980 \mathrm{~s}$ & $1990 \mathrm{~s}$ & $2000 \mathrm{~s}$ & All Sample \\
\hline $\begin{array}{r}0.09 \\
{[0.06]}\end{array}$ & $\begin{array}{l}0.38 * * * \\
{[0.09]}\end{array}$ & $\begin{array}{r}0.31 * * * \\
{[0.07]}\end{array}$ & $\begin{array}{r}0.27 * * * \\
{[0.06]}\end{array}$ \\
\hline $\begin{array}{r}0.16 \\
{[0.12]}\end{array}$ & $\begin{array}{l}0.40 * * * \\
{[0.10]}\end{array}$ & $\begin{array}{l}0.45 * * * \\
{[0.10]}\end{array}$ & $\begin{array}{r}0.27 \\
{[0.06]}\end{array}$ \\
\hline Yes & Yes & Yes & Yes \\
\hline Yes & Yes & Yes & Yes \\
\hline 29 & 38 & 37 & 38 \\
\hline 277 & 329 & 332 & 1,050 \\
\hline 0.48 & 0.47 & 0.46 & 0.23 \\
\hline 0.17 & 0.37 & 0.44 & 0.23 \\
\hline
\end{tabular}

This table reports panel regressions of capital inflows by foreign agents $(C I F)$ on capital outflows by domestic agents $(C O D)$ and, conversely, of $C O D$ on $C I F$. The results are shown for each decade as well as for the entire sample period. All the regressions include country dummies and country-trend dummies. Capital flows are first normalized by trend GDP and then standardized by de-meaning and dividing by the standard deviation at the country level. The figure reports the results for all of the countries in the sample, as well as separately for high-income, upper-middle-income, and lower-middle-income countries. The sample period is from 1970 to 2009. Robust standard errors, clustered at the country-level, are reported in brackets. ${ }^{*}, *$, and $* * *$ mean significant at $10 \%, 5 \%$, and $1 \%$, respectively. 
Table 3

Cyclicality of Capital Flows

\begin{tabular}{|c|c|c|c|c|c|c|}
\hline & \multicolumn{6}{|c|}{ All Countries } \\
\hline & $C I F$ & $C O D$ & $C I F+C O D$ & $C I F$ & $C O D$ & $C I F+C O D$ \\
\hline Trade Balance & $\begin{array}{l}-0.45 * * * \\
{[0.03]}\end{array}$ & $\begin{array}{l}0.23 * * * \\
{[0.04]}\end{array}$ & $\begin{array}{l}-0.16 * * * \\
{[0.04]}\end{array}$ & & & \\
\hline Real GDP Growth & & & & $\begin{array}{l}3.48 * * * \\
{[0.61]}\end{array}$ & $\begin{array}{l}3.69 * * * \\
{[0.56]}\end{array}$ & $\begin{array}{l}4.40 * * * \\
{[0.58]}\end{array}$ \\
\hline $\begin{array}{l}\text { Country Dummies } \\
\text { Country-Trend Dummies } \\
\text { No. of Countries } \\
\text { No. of Observations } \\
\text { R-squared }\end{array}$ & $\begin{array}{r}\text { Yes } \\
\text { Yes } \\
103 \\
3,052 \\
0.37\end{array}$ & $\begin{array}{r}\text { Yes } \\
\text { Yes } \\
103 \\
3,052 \\
0.27\end{array}$ & $\begin{array}{r}\text { Yes } \\
\text { Yes } \\
103 \\
3,052 \\
0.25\end{array}$ & $\begin{array}{r}\text { Yes } \\
\text { Yes } \\
103 \\
3,010 \\
0.25\end{array}$ & $\begin{array}{r}\text { Yes } \\
\text { Yes } \\
103 \\
3,010 \\
0.26\end{array}$ & $\begin{array}{r}\text { Yes } \\
\text { Yes } \\
103 \\
3,010 \\
0.27\end{array}$ \\
\hline \multirow{2}{*}{ R-squared } & \multicolumn{6}{|c|}{ High-Income Countries } \\
\hline & $C I F$ & $C O D$ & $C I F+C O D$ & $C I F$ & $C O D$ & $C I F+C O D$ \\
\hline Trade Balance & $\begin{array}{l}-0.25 * * * \\
{[0.06]}\end{array}$ & $\begin{array}{c}0.19 \\
{[0.07]}\end{array}$ & $\begin{array}{r}0.00 \\
{[0.07]}\end{array}$ & & & \\
\hline Real GDP Growth & & & & $\begin{array}{l}3.58 * * \\
{[1.45]}\end{array}$ & $\begin{array}{l}5.20 \\
{[1.46]}\end{array}$ & $\begin{array}{l}5.17 * * * \\
{[1.41]}\end{array}$ \\
\hline $\begin{array}{l}\text { Country Dummies } \\
\text { Country-Trend Dummies } \\
\text { No. of Countries } \\
\text { No. of Observations } \\
\text { R-squared }\end{array}$ & $\begin{array}{r}\text { Yes } \\
\text { Yes } \\
39 \\
1,300 \\
0.33\end{array}$ & $\begin{array}{r}\text { Yes } \\
\text { Yes } \\
39 \\
1,300 \\
0.33\end{array}$ & $\begin{array}{r}\text { Yes } \\
\text { Yes } \\
39 \\
1,300 \\
0.30\end{array}$ & $\begin{array}{r}\text { Yes } \\
\text { Yes } \\
39 \\
1,287 \\
0.31\end{array}$ & $\begin{array}{r}\text { Yes } \\
\text { Yes } \\
39 \\
1,287 \\
0.35\end{array}$ & $\begin{array}{r}\text { Yes } \\
\text { Yes } \\
39 \\
1,287 \\
0.35\end{array}$ \\
\hline \multirow{2}{*}{ R-squared } & \multicolumn{6}{|c|}{ Upper-Middle-Income Countries } \\
\hline & $C I F$ & $C O D$ & $C I F+C O D$ & $C I F$ & $C O D$ & $C I F+C O D$ \\
\hline Trade Balance & $\begin{array}{l}-0.59 * * * \\
{[0.04]}\end{array}$ & $\begin{array}{l}0.21 \\
{[0.09]}\end{array}$ & $\begin{array}{l}-0.25 * * * \\
{[0.08]}\end{array}$ & & & \\
\hline Real GDP Growth & & & & $\begin{array}{l}3.90 * * * \\
{[0.91]}\end{array}$ & $\begin{array}{l}3.18 \text { *** } \\
{[0.92]}\end{array}$ & $\begin{array}{l}4.47 * * * \\
{[0.87]}\end{array}$ \\
\hline Country Dummies & Yes & Yes & Yes & Yes & Yes & Yes \\
\hline Country-Trend Dummies & Yes & Yes & Yes & Yes & Yes & Yes \\
\hline No. of Countries & 26 & 26 & 26 & 26 & 26 & 26 \\
\hline No. of Observations & 702 & 702 & 702 & 681 & 681 & 681 \\
\hline \multirow[t]{3}{*}{$R$-squared } & 0.46 & 0.23 & 0.27 & 0.24 & 0.22 & 0.27 \\
\hline & \multicolumn{6}{|c|}{ Lower-Middle-Income Countries } \\
\hline & $C I F$ & $C O D$ & $C I F+C O D$ & $C I F$ & $C O D$ & $C I F+C O D$ \\
\hline Trade Balance & $\begin{array}{l}-0.58 * * * \\
{[0.04]}\end{array}$ & $\begin{array}{l}0.30 * * * \\
{[0.05]}\end{array}$ & $\begin{array}{l}-0.27 * * * \\
{[0.05]}\end{array}$ & & & \\
\hline Real GDP Growth & & & & $\begin{array}{l}3.02 \\
{[0.86]}\end{array}$ & $\begin{array}{l}2.95 \\
{[0.78]}\end{array}$ & $\begin{array}{l}3.71 \\
{[0.87]}\end{array}$ \\
\hline Country Dummies & Yes & Yes & Yes & Yes & Yes & Yes \\
\hline Country-Trend Dummies & Yes & Yes & Yes & Yes & Yes & Yes \\
\hline No. of Countries & 38 & 38 & 38 & 38 & 38 & 38 \\
\hline No. of Observations & 1,050 & 1,050 & 1,050 & 1,042 & 1,042 & 1,042 \\
\hline $\mathrm{R}$-squared & 0.40 & 0.23 & 0.20 & 0.19 & 0.18 & 0.18 \\
\hline
\end{tabular}

This table reports panel regressions of capital inflows by foreign agents $(C I F)$, capital outflows by domestic agents $(C O D)$, and total gross capital flows $(C I F+C O D)$ on the trade balance in goods and services and the real GDP growth. All the regressions include country dummies and country-trend dummies. Capital flows are first normalized by trend GDP and then standardized by de-meaning and dividing by the standard deviation at the country level. The figure reports the results for all of the countries in the sample, as well as separately for high-income, upper-middle-income, and lower-middle-income countries. The sample period is from 1970 to 2009 . Robust standard errors, clustered at the countrylevel, are reported in brackets. ${ }^{*}, * *$, and ${ }^{* * *}$ mean significant at $10 \%, 5 \%$, and $1 \%$, respectively. 
Table 4

Capital Flows: Tranquil vs. Crisis Periods

\begin{tabular}{|c|c|c|c|c|}
\hline & All Countries & $\begin{array}{c}\text { High-Income } \\
\text { Countries } \\
\end{array}$ & $\begin{array}{c}\text { Upper-Middle-Income } \\
\text { Countries } \\
\end{array}$ & $\begin{array}{c}\text { Lower-Middle-Income } \\
\text { Countries } \\
\end{array}$ \\
\hline \multicolumn{5}{|c|}{ Net Capital Flows $(C I F-C O D)$} \\
\hline Non-Crisis Years & 0.64 & -0.23 & 0.76 & 1.69 \\
\hline Crisis Years & 1.09 & 3.24 & -0.44 & 1.44 \\
\hline \multicolumn{5}{|c|}{ Total Gross Capital Flows $(C I F+C O D)$} \\
\hline Non-Crisis Years & 16.97 & 26.05 & 12.27 & 8.28 \\
\hline Crisis Years & 3.44 & 18.87 & -5.38 & 4.21 \\
\hline \multicolumn{5}{|c|}{ Capital Inflows by Foreign Agents $(C I F)$} \\
\hline Non-Crisis Years & 8.81 & 12.91 & 6.52 & 4.99 \\
\hline Crisis Years & 2.26 & 11.06 & -2.91 & 2.83 \\
\hline \multicolumn{5}{|c|}{ Capital Outflows by Domestic Agents (COD) } \\
\hline Non-Crisis Years & 8.17 & 13.14 & 5.75 & 3.30 \\
\hline Crisis Years & 1.17 & 7.81 & -2.47 & 1.38 \\
\hline No. of Countries & 103 & 39 & 26 & 38 \\
\hline
\end{tabular}

This table shows the average of capital inflows by foreign agents $(C I F)$, capital outflows by domestic agents $(C O D)$, total gross capital flows $(C I F+C O D)$, and net capital inflows $(C I F-C O D)$ around crisis and non-crisis years. The definition of crisis years is described in Section 2 of the main text and the years are listed in Appendix Table 1. Non-crisis years capture all the years in the sample not identified with a crisis. Capital flows are scaled by trend GDP. The figure reports the results for all of the countries in the sample, as well as separately for high-income, uppermiddle-income, and lower-middle-income countries. The sample period is from 1970 to 2009. 
Table 5

Capital Flows around Crises

Year $\mathrm{t}-2$

Year $\mathrm{t}-1$

Crisis Year

Year $t+1$

Year $\mathrm{t}+2$

One-Sided Wald Tests:

Avg. (Crisis Year, Year t - 1) - Year t $-2<0$

Crisis Year - Avg. (Year t - 1, Year $t-2)<0$

Avg. (Crisis Year, Year $t+1)-$ Avg. (Year $t-1$, Year $t-2)<0$

Country Dummies

Country-Trend Dummie

No. of Crises

No. of Countries

No. of Observation

Other

Portfolio

Portfolio

$\begin{array}{cccc}\begin{array}{c}\text { Direct } \\ \text { Investments }\end{array} & \begin{array}{c}\text { Other } \\ \text { Investments }\end{array} & \begin{array}{c}\text { Portfolio } \\ \text { Debt Flows }\end{array} & \begin{array}{c}\text { Portfolio } \\ \text { Equity Flows }\end{array}\end{array}$

\begin{tabular}{|c|c|c|c|c|}
\hline$C I F$ & Investments & Investments & Debt Flows & Equity Flows \\
\hline $0.25^{* * *}$ & 0.01 & $0.26 * * *$ & $0.19 * * *$ & 0.02 \\
\hline [0.083] & {$[0.057]$} & [0.078] & [0.071] & {$[0.080]$} \\
\hline $0.23 * *$ & 0.04 & $0.31 * * *$ & 0.05 & -0.00 \\
\hline [0.101] & {$[0.065]$} & [0.098] & {$[0.075]$} & {$[0.076]$} \\
\hline$-0.36 * * * *$ & -0.13 * & $-0.28 * * * *$ & -0.11 & $-0.23 * * *$ \\
\hline$[0.086]$ & {$[0.064]$} & [0.095] & {$[0.067]$} & {$[0.068]$} \\
\hline$-0.48 * * *$ & $-0.21 * * *$ & $-0.45 * * *$ & $-0.17 * *$ & -0.06 \\
\hline$[0.076]$ & {$[0.062]$} & [0.081] & {$[0.074]$} & [0.053] \\
\hline$-0.36 * * *$ & $-0.14 * *$ & $-0.31 * * *$ & $-0.21 * * *$ & -0.01 \\
\hline [0.072] & {$[0.068]$} & [0.075] & {$[0.066]$} & [0.054] \\
\hline
\end{tabular}

\begin{tabular}{|c|c|c|c|c|c|}
\hline \multirow[b]{2}{*}{$C O D$} & \multicolumn{5}{|c|}{ COD Components } \\
\hline & $\begin{array}{c}\text { Direct } \\
\text { Investments }\end{array}$ & $\begin{array}{c}\text { Other } \\
\text { Investments }\end{array}$ & $\begin{array}{l}\text { Portfolio } \\
\text { Debt Flows }\end{array}$ & $\begin{array}{c}\text { Portfolio } \\
\text { Equity Flows }\end{array}$ & Reserves \\
\hline 0.05 & 0.02 & $0.18 * *$ & 0.00 & 0.04 & -0.00 \\
\hline$[0.085]$ & {$[0.046]$} & {$[0.087]$} & [0.063] & [0.062] & {$[0.082]$} \\
\hline-0.06 & $0.12 * *$ & $0.29 * * *$ & -0.08 & 0.01 & $-0.35 * * *$ \\
\hline$[0.088]$ & [0.058] & [0.089] & [0.055] & [0.059] & {$[0.076]$} \\
\hline$-0.35 * * * *$ & -0.02 & -0.00 & $-0.16 * *$ & $-0.23 * * *$ & $-0.32 * * * *$ \\
\hline$[0.075]$ & [0.051] & {$[0.084]$} & [0.064] & [0.070] & {$[0.080]$} \\
\hline-0.09 & $-0.18 * * *$ & 0.02 & $-0.15 * *$ & -0.09 & 0.06 \\
\hline [0.073] & [0.045] & [0.080] & [0.072] & [0.064] & {$[0.087]$} \\
\hline$-0.11 *$ & $-0.16 * * *$ & -0.13 & 0.06 & $-0.07 *$ & 0.03 \\
\hline [0.063] & [0.035] & {$[0.080]$} & [0.064] & [0.043] & {$[0.067]$} \\
\hline
\end{tabular}

$\begin{array}{llrrr}-0.32 * * * & -0.06 & -0.25 * * * & -0.22 * * * & -0.14 * \\ -0.60 * * * & -0.16 * * * & -0.57^{* * * *} & -0.23^{* * * *} & -0.24 * * * \\ -0.66 * * * & -0.20^{* * *} & -0.65 * * * & -0.26^{* * *} & -0.16 * * \\ \text { Yes } & \text { Yes } & \text { Yes } & \text { Yes } & \text { Yes } \\ \text { Yes } & \text { Yes } & \text { Yes } & \text { Yes } & \text { Yes } \\ 238 & 238 & 238 & 238 & 238 \\ 103 & 103 & 103 & 103 & 103 \\ 3,021 & 3,021 & 3,021 & 3,006 & 3,006 \\ 0.27 & 0.33 & 0.21 & 0.18 & 0.12\end{array}$

$\begin{array}{ccc}-0.26 * * * & 0.03 & -0.04 \\ -0.35 * * * & -0.09 * * & -0.24 * * \\ -0.22 * * & -0.17 * * * & -0.23 * * \\ \text { Yes } & \text { Yes } & \text { Yes } \\ \text { Yes } & \text { Yes } & \text { Yes } \\ 238 & 238 & 238 \\ 103 & 103 & 103 \\ 3,021 & 3,021 & 3,021 \\ 0.25 & 0.32 & 0.15\end{array}$

$-0.12 *$

$-0.15 * * \quad-0.34 * * *$

$\begin{array}{lll}-0.12 * & -0.15 * * & -0.34 \\ -0.12 * & -0.26 * * & -0.15 * \\ -0.12 * & -0.19 * * * & 0.05\end{array}$

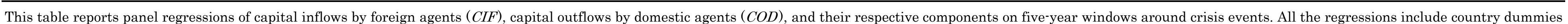

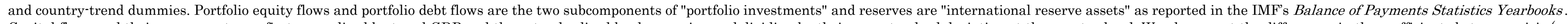

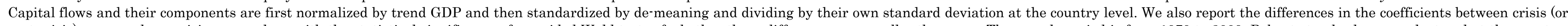

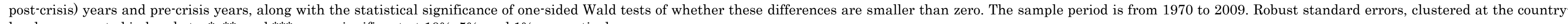
level, are reported in brackets. ${ }^{*}, * *$, and ${ }^{* * *}$ mean significant at $10 \%, 5 \%$, and $1 \%$, respectively. 
Table 6

Capital Flows around Crises by Income Level

Year $\mathrm{t}-2$

Year $\mathrm{t}-1$

Crisis Year

Year $\mathrm{t}+1$
Year $\mathrm{t}+2$

One-Sided Wald Tests:

Avg. (Crisis Year, Year t - 1) - Year t $-2<0$

(Year $t-1$, Year $t-2)<0$

Avg. (Crisis Year, Year $t+1$ ) - Avg. (Year $t-1$, Year $t-2)<0$

Country Dummie

Country-Trend Dummies

No. of Crises

No. of Countries
No. of Observations

$\mathrm{R}$-squared

Year $\mathrm{t}-2$

Year t - 1

Crisis Year

Year $t+1$

Year $\mathrm{t}+2$

One-Sided Wald Tests:

Avg. (Crisis Year, Year t - 1) - Year t $-2<0$

(Year $t-1$ Year $t-2)<0$

Avg. (Crisis Year, Year $t+1)$ - Avg. (Year $t-1$, Year $t-2)<0$ Country Dummies

Country-Trend Dummies

No. of Crises

No. of Observations

$\mathrm{R}$-squared

Year $\mathrm{t}-2$

Year t - 1

Year $t+1$

Year $t+1$

One-Sided Wald Tests:

Avg. (Crisis Year, Year $\mathrm{t}-1)$ - Year $\mathrm{t}-2<0$

Avg. (Crisis Year, Year t +1$)$ - Avg. (Year t - 1, Year t - 2) $<0$

Country Dummies

Country-Trend Dummies

o. of Crises

No. of Observations

R-squared

Therts panel regressions of capital inflows by foreign agents $(C I F)$, capital outflows by domestic agents $(C O D)$,

country-trend dummies. The table reports regressions separately for high-income, upper-middle-income, and lower-middle-income countries. Portfolio equity flows and portfolio debt flows are the two subcomponents of "portfolio investments" and standard deviation at the country level. We also report the differences in the coefficients between crisis (or post-crisis) years and pre-crisis years, along with the statistical significance of one-sided Wald tests of whether these differences are smaller than zero. The sample period is from 1970 to 2009. Robust standard errors, clustered at the country-level, are reported in brackets. ***, and *** mean significant at 10\%, $5 \%$, and $1 \%$, respectively.

\begin{tabular}{|c|c|c|c|c|c|c|c|c|c|c|}
\hline \multirow[b]{2}{*}{ CIF } & \multicolumn{4}{|c|}{ CIF Components } & \multirow[b]{2}{*}{$C O D$} & \multicolumn{5}{|c|}{ COD Components } \\
\hline & $\begin{array}{c}\text { Direct } \\
\text { Investments }\end{array}$ & $\begin{array}{c}\text { Other } \\
\text { Investments }\end{array}$ & $\begin{array}{c}\text { Portfolio } \\
\text { Debt Flows }\end{array}$ & $\begin{array}{c}\text { Portfolio } \\
\text { Equity Flows }\end{array}$ & & $\begin{array}{c}\text { Direct } \\
\text { Investments }\end{array}$ & $\begin{array}{c}\text { Other } \\
\text { Investments }\end{array}$ & $\begin{array}{c}\text { Portfolio } \\
\text { Debt Flows }\end{array}$ & $\begin{array}{c}\text { Portfolio } \\
\text { Equity Flows }\end{array}$ & Reserves \\
\hline $0.61 * * *$ & 0.02 & $0.65 * * *$ & 0.35 ** & 0.13 & 0.28 * & 0.18 & $0.64 * * *$ & 0.13 & 0.37 ** & -0.14 \\
\hline $0.98 * * *$ & 0.12 & $1.11 * * *$ & 0.46 ** & -0.25 & $0.62 * * *$ & $0.51 * * *$ & $0.99 * * *$ & 0.30 * & 0.00 & -0.21 \\
\hline-0.17 & -0.13 & 0.03 & 0.04 & $-0.62 * * *$ & $-0.41 *$ & 0.14 & -0.04 & $-0.47 * * *$ & $-0.79 * * *$ & -0.09 \\
\hline$-0.77 * * *$ & $-0.33 * *$ & $-0.87 * * * *$ & $-0.40 * *$ & 0.01 & $-0.73 * * *$ & $-0.38 * *$ & $-0.87 * * *$ & $-0.64 * * *$ & $-0.55 * * * *$ & 0.57 ** \\
\hline-0.40 * & 0.01 & $-0.50 * *$ & -0.27 & 0.08 & -0.29 & $-0.23 * *$ & $-0.45 *$ & -0.12 & $-0.19 *$ & $0.35 * *$ \\
\hline-0.21 & -0.03 & -0.08 & -0.10 & $-0.57 * *$ & -0.18 & 0.15 & -0.17 & -0.22 & $-0.77 * * *$ & -0.01 \\
\hline$-0.97 * * *$ & -0.20 * & $-0.85 * * *$ & -0.37 * & $-0.56 * *$ & $-0.86 * * *$ & -0.21 & $-0.86 * * *$ & $-0.69 * * *$ & $-0.98 * * *$ & 0.09 \\
\hline$-1.27 * * *$ & $-0.30 * *$ & $-1.30 * * * *$ & $-0.59 * * *$ & -0.25 & $-1.02 * * * *$ & $-0.47 * * *$ & $-1.27 * * *$ & $-0.77 * * *$ & $-0.86 * * *$ & 0.42 \\
\hline Yes & Yes & Yes & Yes & Yes & Yes & Yes & Yes & Yes & Yes & Yes \\
\hline Yes & Yes & Yes & Yes & Yes & Yes & Yes & Yes & Yes & Yes & Yes \\
\hline 45 & 45 & 45 & 45 & 45 & 45 & 45 & 45 & 45 & 45 & 45 \\
\hline 39 & 39 & 39 & 39 & 39 & 39 & 39 & 39 & 39 & 39 & 39 \\
\hline 1,269 & 1,269 & 1,269 & 1,257 & 1,257 & 1,269 & 1,269 & 1,269 & 1,253 & 1,253 & 1,269 \\
\hline 0.36 & 0.27 & 0.22 & 0.29 & 0.15 & 0.35 & 0.38 & 0.21 & 0.34 & 0.31 & 0.07 \\
\hline \multicolumn{11}{|c|}{ Upper-Middle-Income Countries } \\
\hline
\end{tabular}

\begin{tabular}{|c|c|c|c|c|}
\hline \multirow[b]{2}{*}{$C I F$} & \multicolumn{4}{|c|}{ CIF Components } \\
\hline & $\begin{array}{c}\text { Direct } \\
\text { Investments }\end{array}$ & $\begin{array}{c}\text { Other } \\
\text { Investments }\end{array}$ & $\begin{array}{c}\text { Portfolio } \\
\text { Debt Flows }\end{array}$ & $\begin{array}{c}\text { Portfolio } \\
\text { Equity Flows }\end{array}$ \\
\hline 0.17 & 0.02 & 0.17 & 0.08 & 0.00 \\
\hline 0.05 & -0.02 & 0.18 & -0.03 & -0.04 \\
\hline$-0.47 * *$ & -0.17 * & -0.38 ** & -0.16 & $-0.20 * *$ \\
\hline$-0.44 * * *$ & $-0.25 * * *$ & $-0.43 * * *$ & 0.02 & -0.06 \\
\hline$-0.38 * * * *$ & -0.14 & $-0.31 * *$ & $-0.19 * *$ & -0.01 \\
\hline$-0.38^{* * * *}$ & -0.12 & -0.27 * & -0.18 & -0.12 \\
\hline$-0.58 * * *$ & $-0.17 * *$ & $-0.56 * * *$ & -0.19 * & -0.18 \\
\hline$-0.57 * * *$ & $-0.21 * * *$ & $-0.58 * * *$ & -0.10 & -0.11 \\
\hline Yes & Yes & Yes & Yes & Yes \\
\hline Yes & Yes & Yes & Yes & Yes \\
\hline & 88 & 88 & 88 & 88 \\
\hline 26 & 26 & 26 & 26 & 26 \\
\hline 702 & 702 & 702 & 699 & 699 \\
\hline 0.26 & 0.37 & 0.21 & 0.07 & 0.08 \\
\hline
\end{tabular}

\begin{tabular}{|c|c|c|c|c|c|}
\hline \multirow[b]{2}{*}{$C O D$} & \\
\hline & $\begin{array}{c}\text { Direct } \\
\text { Investments }\end{array}$ & $\begin{array}{c}\text { Other } \\
\text { Investments }\end{array}$ & $\begin{array}{c}\text { Portfolio } \\
\text { Debt Flows }\end{array}$ & $\begin{array}{c}\text { Portfolio } \\
\text { Equity Flows }\end{array}$ & Reserves \\
\hline 0.01 & -0.02 & 0.06 & 0.02 & 0.03 & 0.11 \\
\hline$-0.35 * * *$ & 0.06 & -0.01 & $-0.22 * * *$ & 0.06 & $-0.49 * * *$ \\
\hline$-0.37 * * *$ & -0.10 & 0.05 & -0.07 & $-0.19 * *$ & $-0.45 * * *$ \\
\hline 0.05 & -0.11 & 0.07 & 0.02 & 0.02 & 0.04 \\
\hline-0.03 & -0.12 & -0.04 & $0.23 * *$ & -0.09 & -0.02 \\
\hline$-0.37 * *$ & 0.00 & -0.04 & -0.17 & -0.10 & $-0.58 * * *$ \\
\hline 0.20 * & $-0.12 * *$ & 0.03 & 0.03 & $-0.24 * *$ & -0.26 * \\
\hline 0.01 & $-0.13 * * *$ & 0.04 & 0.08 & $-0.13 *$ & -0.02 \\
\hline Yes & Yes & Yes & Yes & Yes & Yes \\
\hline Yes & Yes & Yes & Yes & Yes & Yes \\
\hline 88 & 88 & 88 & 88 & 88 & 88 \\
\hline $\begin{array}{l}00 \\
26\end{array}$ & $\begin{array}{l}00 \\
26\end{array}$ & $\begin{array}{l}00 \\
26\end{array}$ & $\begin{array}{l}00 \\
26\end{array}$ & 26 & $\begin{array}{l}0_{20} \\
26\end{array}$ \\
\hline $\begin{array}{l}20 \\
702\end{array}$ & $\begin{array}{l}20 \\
702\end{array}$ & 702 & 699 & $\begin{array}{l}20 \\
699\end{array}$ & $\begin{array}{l}20 \\
702\end{array}$ \\
\hline 0.22 & 0.30 & 0.15 & 0.14 & $\begin{array}{l}0.16 \\
0.16\end{array}$ & 0.14 \\
\hline
\end{tabular}

\begin{tabular}{|c|c|c|c|c|c|c|c|c|c|c|}
\hline \multirow[b]{2}{*}{$C I F$} & \multicolumn{4}{|c|}{ CIF Components } & \multirow[b]{2}{*}{$C O D$} & \multicolumn{5}{|c|}{ COD Components } \\
\hline & $\begin{array}{c}\text { Direct } \\
\text { Investments } \\
\end{array}$ & $\begin{array}{c}\text { Other } \\
\text { Investments }\end{array}$ & $\begin{array}{c}\text { Portfolio } \\
\text { Debt Flows } \\
\end{array}$ & $\begin{array}{c}\text { Portfolio } \\
\text { Equity Flows }\end{array}$ & & $\begin{array}{c}\text { Direct } \\
\text { Investments }\end{array}$ & $\begin{array}{c}\text { Other } \\
\text { Investments }\end{array}$ & $\begin{array}{c}\text { Portfolio } \\
\text { Debt Flows }\end{array}$ & $\begin{array}{c}\text { Portfolio } \\
\text { Equity Flows } \\
\end{array}$ & Reserves \\
\hline 0.15 & -0.01 & 0.14 & 0.23 ** & 0.01 & -0.01 & -0.02 & 0.06 & -0.05 & -0.08 & -0.02 \\
\hline 0.05 & 0.06 & 0.07 & -0.04 & 0.13 & -0.11 & 0.00 & 0.26 ** & -0.10 & -0.03 & $-0.30 * * *$ \\
\hline$-0.37 * * *$ & -0.10 & $-0.35 * * *$ & -0.13 & -0.08 & $-0.30 * * *$ & -0.03 & -0.05 & -0.08 & -0.01 & $-0.30 * * * *$ \\
\hline$-0.43 * * * *$ & -0.13 & $-0.33 * * *$ & -0.26 ** & -0.09 & 0.03 & $-0.18 * * *$ & $0.31 * * *$ & -0.09 & 0.00 & -0.12 \\
\hline$-0.35 * * *$ & $-0.20 * *$ & $-0.27 * *$ & $-0.21 *$ & -0.03 & -0.14 & $-0.18 * * *$ & -0.13 & -0.01 & 0.01 & -0.05 \\
\hline
\end{tabular}

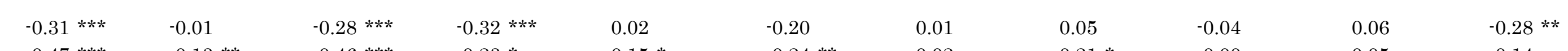

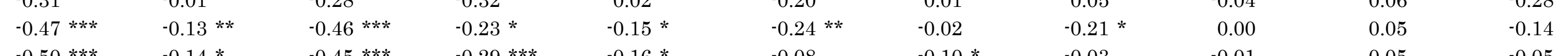

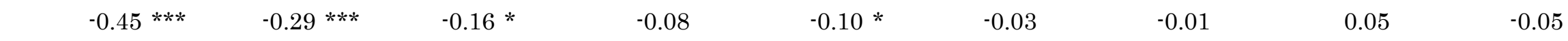

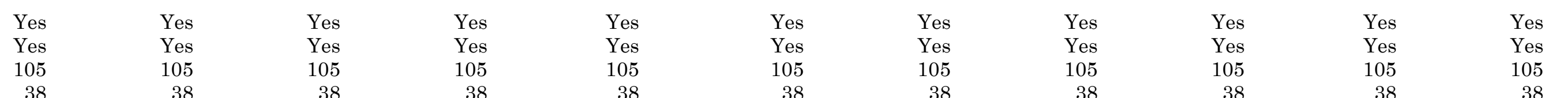

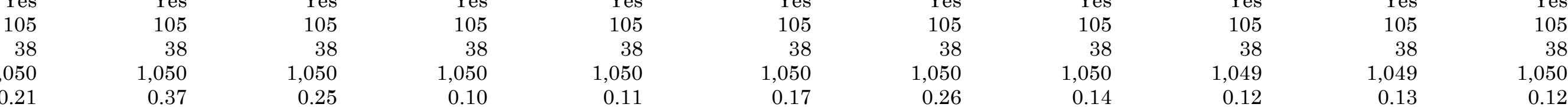

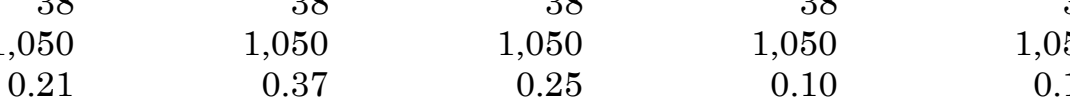

38
0.17

0.1

1,050
0.12

High-Income Countries 
Table 7

Capital Flows around Domestic and Global Crises

\section{Domestic Crise \\ Year $\mathrm{t}-2$ \\ Year $\mathrm{t}-1$ \\ Crisis Year \\ Year $\mathrm{t}+1$ \\ Year $t+2$ \\ Global Crises \\ Year $\mathrm{t}-2$ \\ Year $\mathrm{t}$ - 1 \\ Crisis Year \\ Year $t+1$ \\ Year $t+2$}

One-Sided Wald Tests:

Domestic Crises

Avg. (Crisis Year, Year t - 1) - Year $\mathrm{t}-2<0$

Crisis Year - Avg. (Year t - 1, Year $t-2)<0$

Avg. (Crisis Year, Year $t+1)$ - Avg. (Year $t-1$, Year $t-2)<0$

Global Crises

Avg. (Crisis Year, Year t - 1) - Year t $-2<0$

Crisis Year - Avg. (Year t - 1, Year t - 2) $<0$

Avg. (Crisis Year, Year $t+1)-$ Avg. (Year $t-1$, Year $t-2)<0$

Country Dummies

Country-Trend Dummies

No. of Domestic Crises

No. of Global Crises

No. of Countries

$\mathrm{R}$-squared
No. of Observations

\begin{tabular}{llll}
\multicolumn{4}{c}{ CIF Components } \\
Direct & Other & Portfolio & Portfolio
\end{tabular}

\begin{tabular}{|c|c|c|c|c|c|c|c|c|c|c|}
\hline \multirow[b]{2}{*}{$C I F$} & \multicolumn{4}{|c|}{ CIF Components } & \multirow[b]{2}{*}{$C O D$} & \multicolumn{5}{|c|}{ COD Components } \\
\hline & $\begin{array}{c}\text { Direct } \\
\text { Investments } \\
\end{array}$ & $\begin{array}{c}\text { Other } \\
\text { Investments }\end{array}$ & $\begin{array}{c}\text { Portfolio } \\
\text { Debt Flows }\end{array}$ & $\begin{array}{c}\text { Portfolio } \\
\text { Equity Flows } \\
\end{array}$ & & $\begin{array}{c}\text { Direct } \\
\text { Investments }\end{array}$ & $\begin{array}{c}\text { Other } \\
\text { Investments }\end{array}$ & $\begin{array}{c}\text { Portfolio } \\
\text { Debt Flows }\end{array}$ & $\begin{array}{c}\text { Portfolio } \\
\text { Equity Flows }\end{array}$ & Reserves \\
\hline-0.03 & $-0.15 * *$ & -0.02 & 0.17 * & -0.03 & -0.11 & -0.01 & 0.04 & -0.10 & -0.01 & -0.10 \\
\hline-0.18 * & $-0.21 * * *$ & -0.07 & -0.05 & -0.04 & $-0.22 * *$ & -0.04 & 0.02 & $-0.14 * *$ & -0.06 & $-0.27 * * *$ \\
\hline$-0.50 * * *$ & $-0.31 * * *$ & $-0.44 * * *$ & -0.04 & -0.09 & $-0.26 * * *$ & $-0.11 * *$ & -0.01 & -0.09 & $-0.16 * * *$ & $-0.25 * * *$ \\
\hline$-0.46 * * *$ & $-0.21 * * *$ & $-0.43 * * *$ & -0.06 & -0.02 & 0.06 & $-0.15 * * *$ & 0.09 & -0.06 & -0.06 & 0.17 \\
\hline$-0.28 * * *$ & -0.11 & $-0.27 * * *$ & -0.13 & 0.06 & -0.07 & $-0.15 * * *$ & -0.18 * & 0.10 & -0.05 & 0.14 \\
\hline $0.64 * * *$ & $0.23 * *$ & $0.63 * * *$ & $0.22 * *$ & 0.10 & $0.27 * *$ & 0.05 & $0.37 * * *$ & 0.14 & 0.12 & 0.15 \\
\hline $0.79 * * *$ & $0.37 * * *$ & $0.82 * * *$ & 0.21 * & 0.05 & 0.17 & $0.34^{* * * *}$ & $0.66 * * *$ & 0.00 & 0.11 & $-0.46 * * *$ \\
\hline$-0.23 *$ & 0.10 & -0.12 & $-0.21 * *$ & $-0.44 * * *$ & $-0.50 * * *$ & 0.08 & -0.05 & $-0.26 * * *$ & $-0.34 * *$ & $-0.39 * * *$ \\
\hline$-0.53 * * *$ & $-0.24 * * *$ & $-0.50 * * *$ & $-0.33 * * *$ & -0.07 & $-0.31 * *$ & $-0.27 * * *$ & -0.10 & $-0.26 * * *$ & $-0.12 *$ & -0.06 \\
\hline$-0.44 * * *$ & $-0.17 * *$ & $-0.32 * * *$ & $-0.31 * * *$ & $-0.11 *$ & -0.08 & $-0.16 * * *$ & 0.05 & 0.04 & $-0.10 * *$ & -0.12 \\
\hline$-0.31 * * *$ & $-0.11 *$ & $-0.24 * * *$ & $-0.22 * *$ & -0.04 & -0.13 * & -0.07 * & -0.04 & -0.02 & $-0.10 *$ & -0.16 * \\
\hline$-0.40 * * *$ & $-0.13 * * *$ & $-0.40 * * *$ & -0.10 & -0.06 & -0.10 & $-0.09 * *$ & -0.04 & 0.03 & $-0.13 * *$ & -0.07 \\
\hline$-0.38 * * *$ & $-0.08 *$ & $-0.39 * * *$ & -0.11 & -0.02 & 0.07 & $-0.11 * *$ & 0.01 & 0.05 & -0.08 & 0.15 \\
\hline$-0.36 * * *$ & 0.00 & $-0.28 * *$ & -0.22 * & -0.30 * & $-0.44 * * *$ & 0.16 & -0.07 & $-0.27 * *$ & $-0.24 * *$ & $-0.58 * * *$ \\
\hline$-0.95 * * *$ & $-0.20 * *$ & $-0.85 * * *$ & $-0.43 * * *$ & $-0.52 * * *$ & $-0.72 * * *$ & -0.12 & $-0.57 * * *$ & $-0.33 * * *$ & $-0.46 * * *$ & $-0.24 *$ \\
\hline$-1.10 * * *$ & $-0.37 * * *$ & $-1.04 * * *$ & $-0.49 * * *$ & $-0.33 * * *$ & $-0.63 * * *$ & $-0.29 * * *$ & $-0.59 * * *$ & $-0.33 * * *$ & $-0.35 * * *$ & -0.07 \\
\hline Yes & Yes & Yes & Yes & Yes & Yes & Yes & Yes & Yes & Yes & Yes \\
\hline Yes & Yes & Yes & Yes & Yes & Yes & Yes & Yes & Yes & Yes & Yes \\
\hline 143 & 143 & 143 & 143 & 143 & 143 & 143 & 143 & 143 & 143 & 143 \\
\hline 95 & 95 & 95 & 95 & 95 & 95 & 95 & 95 & 95 & 95 & 95 \\
\hline 102 & 102 & 102 & 102 & 102 & 102 & 102 & 102 & 102 & 102 & 102 \\
\hline 3,019 & 3,019 & 3,019 & 3,004 & 3,004 & 3,019 & 3,019 & 3,019 & 2,999 & 2,999 & 3,019 \\
\hline 0.30 & 0.34 & 0.23 & 0.18 & 0.12 & 0.25 & 0.32 & 0.16 & 0.22 & 0.21 & 0.10 \\
\hline
\end{tabular}

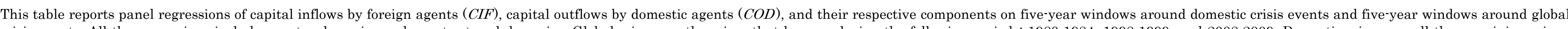

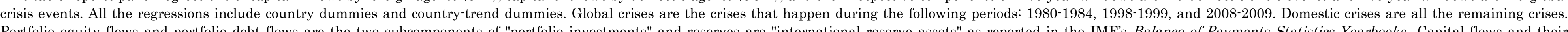

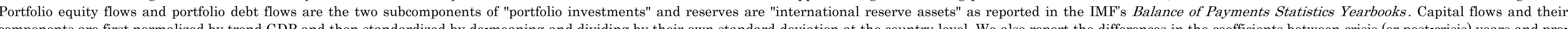

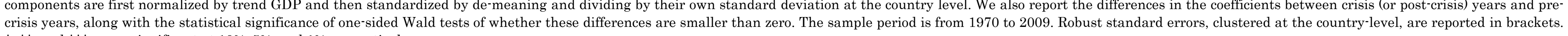
$*, * *$, and $* * *$ mean significant at $10 \%, 5 \%$, and $1 \%$, respectively. 
Table 8

Capital Flows around Banking, Currency, and Debt Crises

Year $\mathrm{t}-2$

Year $\mathrm{t}-1$

Year $t+1$

Year $t+2$

One-Sided Wald Tests:

Avg. (Crisis Year, Year $t$ - 1) - Year $t-2<0$

Crisis Year-Ave (Yeart -1 , Yeart -2$)<0$

Avg (Crisi Year, Year $t+1)$-Avg. (Year $t-1$, Year $t-2)<0$

Country Dummies

Nou Crend Dummie

No. of Countries

No. of Observation

$\mathrm{R}$-squared

Yeart - 2

Year $\mathrm{t}-1$

Crisis Year

Year $t+2$

One-Sided Wald Tests

Avg. (Crisis Year, Year $\mathrm{t}-1)$ - Year $\mathrm{t}-2<0$

Crisis Year- Avs (Yet $t$ - 1, Yeart $-2<<0$

Avg (Crisis Year, Year $t+1)$ - Avg. (Year $t-1$, Year $t-2)<0$

Country Dummies

Country-Trend Dummie

No. of Countries

No. of Countries
No. of Observation

$\mathrm{R}$-squared

(2)

Year $\mathrm{t}-2$
Year $\mathrm{t}-1$
Crisis Year
Year $\mathrm{t}+1$
Year $\mathrm{t}+2$
One-Sided Wald Tests:
Avg. (Crisis Year, Year $\mathrm{t}-1$ ) - Year $\mathrm{t}-2<0$
Crisis Year - Avg. (Year $\mathrm{t}-1$, Year $\mathrm{t}-2)<0$
Avg. (Crisis Year, Year $\mathrm{t}+\mathrm{1}$ ) - Avg. (Year $\mathrm{t}-1$, Year $\mathrm{t}-2)<0$
Country Dummies
Country-Trend Dummies
No. of Crises
No. of Countries
No. of Observations
$\mathrm{R}$ - squared

his table reports panel regressions of capital inflows by foreign agents $(C I F)$, capital outflows by domestic agents $(C O D)$, and their respective conp

Banking Crise

\begin{tabular}{|c|c|c|c|c|}
\hline \multirow[b]{2}{*}{$C I F$} & \multicolumn{4}{|c|}{ CIF Components } \\
\hline & $\begin{array}{c}\text { Direct } \\
\text { Investments }\end{array}$ & $\begin{array}{c}\text { Other } \\
\text { Investments }\end{array}$ & $\begin{array}{c}\text { Portfolio } \\
\text { Debt Flows }\end{array}$ & $\begin{array}{c}\text { Portfolio } \\
\text { Equity Flows } \\
\end{array}$ \\
\hline $0.45 * * *$ & 0.14 & $0.40 * * *$ & $0.27 * *$ & 0.05 \\
\hline $0.73^{* * * *}$ & 0.23 * & $0.73 * * *$ & $0.28 * *$ & 0.09 \\
\hline-0.10 & -0.01 & -0.05 & 0.09 & $-0.32 * *$ \\
\hline$-0.52 * * *$ & $-0.17 * *$ & $0.54 * * *$ & -0.19 * & 0.16 ** \\
\hline$-0.25 * *$ & -0.06 & $-0.29 * *$ & -0.07 & 0.06 \\
\hline-0.14 * & -0.03 & -0.06 & -0.09 & -0.17 \\
\hline$-0.69 * * *$ & $-0.20 * * * *$ & $-0.62 * * * *$ & -0.19 * & -0.39 ** \\
\hline$-0.90 * * * *$ & $-0.28 * * *$ & $-0.86 * * *$ & $-0.33 * * *$ & $-0.31 * *$ \\
\hline Yes & Yes & Yes & Yes & Yes \\
\hline Yes & Yes & Yes & Yes & Yes \\
\hline 97 & 97 & 97 & 97 & 97 \\
\hline 98 & 98 & 98 & 98 & 98 \\
\hline 2,878 & 2,878 & 2,878 & 2,863 & 2,863 \\
\hline 0.26 & 0.33 & 0.20 & 0.17 & 0.12 \\
\hline
\end{tabular}

\begin{tabular}{|c|c|c|c|c|c|c|c|c|c|c|}
\hline & & & & \multicolumn{4}{|c|}{ COD Components } & \\
\hline \multirow[b]{2}{*}{$C I F$} & Direct & Other & Portfolio & Portfolit & \multirow[b]{2}{*}{$C O D$} & Direct & Other & Portfolio & Portfoli & \\
\hline & Investments & Investments & Debt Flows & Equity Flows & & Investments & $\begin{array}{l}\text { Unvere } \\
\text { Investments }\end{array}$ & $\begin{array}{l}\text { Porrtonio } \\
\text { Debt Flows }\end{array}$ & $\begin{array}{l}\text { Portionio } \\
\text { Equity Flows }\end{array}$ & Reserves \\
\hline 0.02 & -0.09 & 0.00 & $0.23 * *$ & 0.07 & -0.20 * & $-0.12 * *$ & -0.02 & -0.08 & -0.03 & $-0.22 *$ \\
\hline-0.09 & -0.17 * & 0.06 & 0.01 & -0.00 & $-0.43^{* * * *}$ & -0.07 & 0.21 * & $-0.25 * * *$ & 0.02 & $-0.69 * * * *$ \\
\hline$-0.61 * * *$ & $-0.26 * * * *$ & $-0.46 * * *$ & $-0.23 * * *$ & -0.14 * & $-0.34 * * *$ & $-0.17 * *$ & 0.05 & $-0.27 * * *$ & -0.11 & $-0.42 * * *$ \\
\hline$-0.57 * * *$ & $-0.34 * * *$ & $-0.46 * * *$ & -0.16 & -0.02 & 0.01 & $-0.20 * * *$ & -0.03 & -0.16 * & -0.07 & 0.12 \\
\hline$-0.48^{* * * *}$ & $-0.27 * * *$ & $-0.35 * * *$ & $-0.26 * * *$ & 0.02 & -0.17 * & $-0.22 * * * *$ & -0.12 & -0.02 & -0.10 * & -0.09 \\
\hline$-0.37 * * *$ & $-0.13 * *$ & $-0.20 * *$ & $-0.34 * * *$ & -0.14 & -0.19 * & 0.00 & 0.15 & $-0.18 * *$ & -0.02 & $-0.34 * *$ \\
\hline$-0.58 * * *$ & $-0.13 * *$ & $-0.49 * * *$ & $-0.35 * * *$ & $-0.18 * *$ & -0.03 & $-0.08 * *$ & -0.05 & $-0.11 *$ & -0.11 & 0.04 \\
\hline$-0.56 * * *$ & $-0.17 * * *$ & $-0.49 * * *$ & $-0.32 * * *$ & -0.12 * & 0.15 & $-0.09 * * *$ & -0.09 & -0.05 & -0.09 & 0.31 \\
\hline Yes & Yes & Yes & Yes & Yes & Yes & Yes & Yes & Yes & Yes & Yes \\
\hline Yes & Yes & Yes & Yes & Yes & Yes & Yes & Yes & Yes & Yes & Yes \\
\hline 100 & 100 & 100 & 100 & 100 & 100 & 100 & 100 & 100 & 100 & 100 \\
\hline 98 & 98 & 98 & 98 & 98 & 98 & 98 & 98 & 98 & 98 & 98 \\
\hline 2,878 & 2,878 & 2,878 & 2,863 & 2,863 & 2,878 & 2,878 & 2,878 & 2,858 & 2,858 & 2,878 \\
\hline 0.25 & 0.33 & 0.19 & 0.17 & 0.11 & 0.24 & 0.31 & 0.13 & 0.21 & 0.21 & 0.10 \\
\hline \multicolumn{11}{|c|}{ Debt Crises } \\
\hline \multicolumn{5}{|c|}{ CIF Components } & & \multicolumn{5}{|c|}{ COD Components } \\
\hline$C I F$ & $\begin{array}{c}\text { Direct } \\
\text { Investments }\end{array}$ & $\begin{array}{c}\text { Other } \\
\text { Investments }\end{array}$ & $\begin{array}{c}\text { Portfolio } \\
\text { Debt Flows }\end{array}$ & $\begin{array}{c}\text { Portfolio } \\
\text { Equity Flows }\end{array}$ & $C O D$ & $\begin{array}{c}\text { Direct } \\
\text { Investments }\end{array}$ & $\begin{array}{c}\text { Other } \\
\text { Investments }\end{array}$ & $\begin{array}{c}\text { Portfolio } \\
\text { Debt Flows }\end{array}$ & $\begin{array}{c}\text { Portfolio } \\
\text { Equity Flows }\end{array}$ & Reserves \\
\hline $0.22 * *$ & 0.02 & $0.33 * * *$ & -0.05 & -0.06 & 0.03 & 0.04 & 0.18 & 0.01 & 0.09 & -0.06 \\
\hline-0.14 & -0.05 & -0.09 & -0.08 & -0.13 & $-0.29 * *$ & 0.01 & -0.05 & -0.13 * & -0.03 & $-0.42 * * *$ \\
\hline$-0.65 * * * *$ & $-0.24 * * *$ & $-0.58 * * *$ & $-0.30 * *$ & -0.18 & $-0.37 * * *$ & -0.05 & $-0.28 * *$ & -0.07 & -0.07 & $-0.23 * *$ \\
\hline$-0.61 * * *$ & -0.24 * & $-0.50 * * *$ & $-0.31 * * *$ & -0.09 & -0.04 & $-0.18 * *$ & 0.18 & -0.03 & -0.01 & -0.15 \\
\hline$-0.47 * * *$ & $-0.23 * *$ & $-0.35 * * *$ & $-0.35 * * *$ & -0.07 & -0.04 & -0.07 & $-0.24 * *$ & -0.04 & -0.06 & 0.08 \\
\hline$-0.62 * * *$ & $-0.17 * *$ & $-0.67 * * *$ & -0.14 & -0.10 & -0.36 ** & -0.06 & $-0.35^{* * *}$ & -0.11 & -0.14 & -0.27 * \\
\hline$-0.69 * * *$ & $-0.23 * * *$ & $-0.70 * * *$ & -0.24 * & -0.09 & -0.24 * & -0.08 & $-0.35 * * *$ & -0.01 & -0.10 & 0.01 \\
\hline$-0.67 * * * *$ & $-0.23 * *$ & $-0.66 * * *$ & $-0.24 * *$ & -0.04 & -0.08 & $-0.14 * *$ & -0.12 & 0.01 & -0.07 & 0.05 \\
\hline Yes & Yes & Yes & Yes & Yes & Yes & Yes & Yes & Yes & Yes & Yes \\
\hline Yes & Yes & Yes & Yes & Yes & Yes & Yes & Yes & Yes & Yes & Yes \\
\hline 80 & 80 & 80 & 80 & 80 & 80 & 80 & 80 & 80 & 80 & 80 \\
\hline $\begin{array}{r}00 \\
102\end{array}$ & $\begin{array}{r}00 \\
102\end{array}$ & $\begin{array}{l}00 \\
102\end{array}$ & $\begin{array}{r}00 \\
102\end{array}$ & $\begin{array}{l}\text { O0 } \\
102\end{array}$ & $\begin{array}{l}00 \\
102\end{array}$ & $\begin{array}{l}00 \\
102\end{array}$ & $\begin{array}{l}00 \\
102\end{array}$ & $\begin{array}{l}00 \\
102\end{array}$ & $\begin{array}{r}00 \\
102\end{array}$ & $\begin{array}{r}00 \\
102\end{array}$ \\
\hline 2,877 & 2,877 & $\begin{array}{l}1,87 \\
2,877\end{array}$ & $\begin{array}{r}102 \\
2,862\end{array}$ & $\begin{array}{l}102 \\
2,862\end{array}$ & 2,877 & 2,877 & 2,877 & 2,858 & $\begin{array}{l}102 \\
2,858\end{array}$ & $\begin{array}{l}102 \\
2,877\end{array}$ \\
\hline $\begin{array}{l}2,011 \\
0.25\end{array}$ & $\begin{array}{r}0,32 \\
0.32\end{array}$ & 0.19 & $\begin{array}{r}2,002 \\
0.17\end{array}$ & $\begin{array}{r}2,002 \\
0.12\end{array}$ & 0.24 & $\begin{array}{r}0.31 \\
0.32\end{array}$ & 0.14 & $\begin{array}{r}r, 000 \\
0.21\end{array}$ & $\begin{array}{r}\text {, } \\
0.210\end{array}$ & 0.08 \\
\hline
\end{tabular}

the regressions include country dummies and country-trend dummies. Portfolive cempity flows and portfolio debt flows are the two subcomponents of "pantfolio invest crises

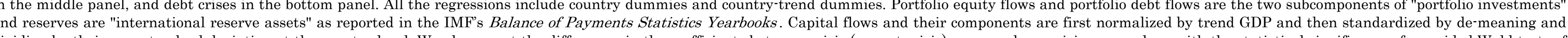
whether these differences are smaller than zero. The sample period is from 1970 to 2009. Robust standard errors, clustered at the country-level, are reported in brackets. ****, and **** mean significant at $10 \%$, 5\%, tests of respectively.

\begin{tabular}{|c|c|c|c|c|c|}
\hline \multirow[b]{2}{*}{$C O D$} & \multicolumn{5}{|c|}{ COD Components } \\
\hline & $\begin{array}{c}\text { Direct } \\
\text { Investments }\end{array}$ & $\begin{array}{c}\text { Other } \\
\text { Investments }\end{array}$ & $\begin{array}{l}\text { Portfolio } \\
\text { Debt Flows }\end{array}$ & $\begin{array}{c}\text { Portfolio } \\
\text { Equity Flows }\end{array}$ & Reserves \\
\hline $0.28 * * *$ & 0.12 & $0.37 * * *$ & 0.03 & 0.07 & 0.19 * \\
\hline $0.42 * * *$ & $0.38 * * *$ & $0.54 * * *$ & 0.04 & 0.00 & 0.03 \\
\hline$-0.52 * * * *$ & 0.12 & 0.01 & -0.21 * & $-0.44 * * *$ & $-0.49 * * *$ \\
\hline$-0.34 * * *$ & $-0.21 * *$ & -0.15 & -0.18 * & -0.25 ** & 0.04 \\
\hline-0.03 & $-0.15 * *$ & -0.16 & 0.23 * & -0.10 & $0.27 * *$ \\
\hline
\end{tabular}

$\begin{array}{llllll}-0.33 * * * & 0.13 & -0.10 & -0.12 & -0.29 * * * & -0.42 * * *\end{array}$

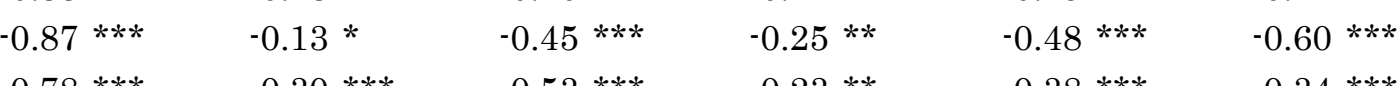

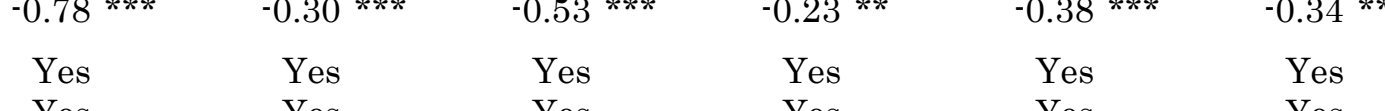

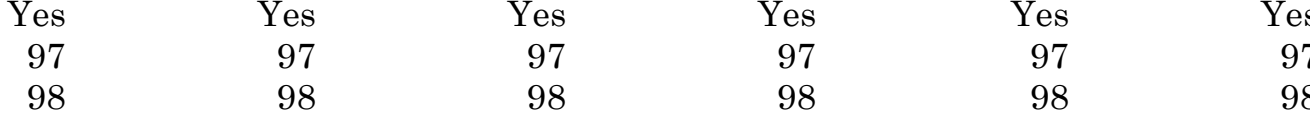

$\begin{array}{rrrrrr}2,978 & 2,878 & 98 & 98 & 98 & 98 \\ 0.25 & 0.32 & 0.14 & 2,858 & 2,858 & 2,878 \\ & & & 0.21 & 0.21 & 0.09\end{array}$

urrency Crises 
Appendix Table 1

Crisis Years

\begin{tabular}{|c|c|c|c|}
\hline \multicolumn{2}{|c|}{ High-Income Countries } & \multicolumn{2}{|c|}{ Upper-Middle-Income Countries (cont.) } \\
\hline Country & Crisis Years & Country & Crisis Years \\
\hline Australia & - & Malaysia & 1997,1998 \\
\hline Austria & 2008 & Mauritius & - \\
\hline Bahamas, The & - & Mexico & 1977, 1981, 1982, 1994, 1995 \\
\hline Barbados & - & Panama & 1983, 1988 \\
\hline Belgium-Luxembourg & - & Poland & 1981, 1992 \\
\hline Canada & - & Romania & 1981, 1986, 1990, 1996 \\
\hline Cyprus & - & Russian Federation & $1991,1998,2008$ \\
\hline Czech Republic & 1996 & South Africa & 1984, 1985, 1989, 1993 \\
\hline Denmark & 2008 & Turkey & 1978, 1982, 1984, 1991, 1996, \\
\hline Estonia & 1992 & & 2000,2001 \\
\hline Finland & 1991,1993 & Uruguay & 1972, 1981, 1983, 1987, 1990, \\
\hline France & 2008 & & 2002,2003 \\
\hline Germany & 2008 & Venezuela, R.B. & 1983, 1984, 1989, 1990, 1994, \\
\hline Greece & 1983,2008 & & $1995,2002,2004$ \\
\hline Hong Kong & - & & \\
\hline Hungary & 1991,2008 & \multicolumn{2}{|c|}{ Lower-Middle-Income Countries } \\
\hline Iceland & $1975,1981,1989,2008$ & Country & Crisis Years \\
\hline Ireland & 2008 & Albania & $\overline{1991,1994,1997}$ \\
\hline Israel & $1975,1977,1980,1985$ & Algeria & 1988, 1990, 1991, 1994 \\
\hline Italy & 1981 & Angola & 1976, 1985, 1991, 1992, 1996 \\
\hline Japan & 1997 & Armenia & 1994 \\
\hline Korea, Rep. & $1997,1998,2008$ & Azerbaijan, Rep. of & 1994,1995 \\
\hline Kuwait & 1982 & Bolivia & 1973, 1980, 1981, 1982, 1986, \\
\hline Malta & - & & 1994 \\
\hline Netherlands & 2008 & Bosnia and Herzegovina & 1992 \\
\hline New Zealand & - & China, P.R.: Mainland & 1998 \\
\hline Norway & 1991 & Colombia & $1982,1985,1998$ \\
\hline Oman & - & Congo, Republic of & $1983,1991,1992,1994$ \\
\hline Portugal & 1983,2008 & Dominican Republic & $1982,1985,1990,2003,2005$ \\
\hline Saudi Arabia & - & Ecuador & 1982, 1998, 1999, 2008 \\
\hline Singapore & - & Egypt & $1979,1980,1984,1990$ \\
\hline Slovak Republic & 1998 & El Salvador & $1981,1986,1989$ \\
\hline Slovenia & 1992,2008 & Georgia & 1991, 1992, 1999 \\
\hline Spain & $1977,1983,2008$ & Guatemala & 1986,1989 \\
\hline Sweden & $1991,1993,2008$ & Honduras & 1981, 1990 \\
\hline Switzerland & 2008 & India & 1972,1993 \\
\hline Trinidad and Tobago & 1986,1988 & Indonesia & 1979, 1997, 1998, 2002 \\
\hline United Kingdom & 2007 & Jamaica & 1978, 1981, 1983, 1987, 1991, \\
\hline United States & 1988,2007 & & 1996 \\
\hline & & Jordan & 1989 \\
\hline Upper-M & Income Countries & Macedonia & 1992,1993 \\
\hline Country & Crisis Years & Moldova & 1998, 1999, 2002 \\
\hline Argentina & 1975, 1980, 1981, 1982, 1987, & Mongolia & 1990, 1997, 2008 \\
\hline & 1989, 1995, 2001, 2002, 2007 & Morocco & 1980, 1981, 1983, 1986 \\
\hline Belarus & 1994, 1995, 1999, 2009 & Namibia & 1984 \\
\hline Botswana & 1984 & Nicaragua & $1979,1985,1990,2000$ \\
\hline Brazil & 1976, 1982, 1983, 1986, 1987, & Pakistan & $1972,1998,1999$ \\
\hline & 1990, 1992, 1994, 1999, 2002 & Paraguay & $1984,1986,1989,1995,2002$ \\
\hline Bulgaria & 1990,1996 & & 2003 \\
\hline Chile & $\begin{array}{l}1972,1974,1976,1981,1982, \\
1983\end{array}$ & Peru & $\begin{array}{l}\text { 1976, 1978, 1980, 1981, 1983, } \\
1984,1985,1988\end{array}$ \\
\hline Costa Rica & 1981, 1983, 1987, 1991, 1994 & Philippines & 1981, 1983, 1997, 1998 \\
\hline Croatia & 1992,1998 & Sri Lanka & 1978, 1979, 1981, 1989, 1996 \\
\hline Equatorial Guinea & $1980,1983,1994$ & Swaziland & 1985,1995 \\
\hline Gabon & $1986,1994,1999$ & Syrian Arab Republic & 1988 \\
\hline Iran, I.R. of & $1978,1985,1993,2000$ & Thailand & 1983, 1997, 1998 \\
\hline Kazakhstan & 1999,2008 & Tunisia & 1979,1991 \\
\hline Latvia & $1992,1995,2008$ & Ukraine & 1998,2008 \\
\hline Libya & 2002 & Vietnam & 1972, 1981, 1985, 1987, 1997 \\
\hline Lithuania & 1992,1995 & & \\
\hline
\end{tabular}

This table shows the crisis years in each country in the sample using all types of crises (banking, currency, and debt). 